\title{
Ascophyllum nodosum Application and Pre-Sowing Stimulation with Low-Frequency Magnetic Field as Factors Influencing Oat Grains (Avena sativa L.) Composition
}

\author{
Barbara Drygaś $^{1, *(\mathbb{D}}$, Joanna Depciuch ${ }^{2}{ }^{(\mathbb{0}}$, Grzegorz Zaguła $^{1}$ and Czesław Puchalski ${ }^{1}$ \\ 1 Department of Bioenergetics, Food Analysis and Microbiology, Institute of Food Technology and Nutrition, \\ College of Natural Science, Rzeszow University, Ćwiklińskiej 2D, 35-601 Rzeszow, Poland; \\ g_zagula@ur.edu.pl (G.Z.); cpuchal@ur.edu.pl (C.P.) \\ 2 Institute of Nuclear Physics, Polish Academy of Sciences, 31-342 Krakow, Poland; joanna.depciuch@ifj.edu.pl \\ * Correspondence: badrygas@ur.edu.pl
}

Received: 29 June 2020; Accepted: 6 August 2020; Published: 8 August 2020

check for updates

\begin{abstract}
In this study, we tested the influence of two experimental factors on the composition of oat grain Avena sativa under the conditions of a three-year field study. The first factor (factor A) consisted of an Ascophyllum nodosum application, an organism classified in the Chromista kingdom, class Phaeophyceae, order Fucales; the second factor was the pre-sowing stimulation of seeds with a low-frequency magnetic field with known parameters. The basic organic components and mineral composition of the grain were tested. It was determined, among other things, that fertilization with algae leads to reduced ash content in oat grain, increased content of sodium, reduced calcium and iron content, and increased content of starch components (amyloses and amylopectins). The application of pre-sowing seed stimulation resulted in increased copper content in the progeny. No significant interactions could be observed between the factors in forming the chemical composition of oat grain.
\end{abstract}

Keywords: Ascophyllum nodosum; algae; oat; magnetic field; crop

\section{Introduction}

Ascophyllum nodosum is an organism classified in the domain of Eukaryota, the kingdom of Chromista, phylum Ochrophyta (Heterokontophyta), brown algae class (Phaeophyceae), subclass Fucophycidae, order Fucales, family Fucaceae, and it is the sole representative of the genus Ascophyllum [1]. It is one of the algae species most valued in agriculture and used in nutrient supplementation and as a plant biostimulant [2] to increase growth and yield. This is due to the control of the activity of enzymes participating in the uptake of mineral components, thus favoring a more efficient use of the mineral nutrition process [3]. Examples of the affect $A$. nodosum has on plants have been described in the literature, e.g., increasing resistance to extreme temperatures and other stress factors [4-8], positive impact on soil and beneficial microorganisms [9-14], and as a plant protection agent $[15,16]$.

A study with commercial preparation Bio-Algeen S-90 (based on A. nodosum) demonstrated that its application resulted in an increased content of nitrogen, potassium, calcium, phosphorus, iron, and zinc in tomato fruit. The number of applications (by spraying) was reported to determine the water uptake index of plants [17]. Interestingly, experiments on lettuce utilizing Bio-Algeen S-90 did not produce differences in the content of the following elements: nitrogen, phosphorus, and potassium [18].

There is a wide range of scientific experiments on the effects of a magnetic field on the growth and development of plants. A laboratory study on the biological influence of magnetic fields demonstrated 
that they may produce or alter various phenomena $[19,20]$. Magnetic fields are an environmental factor influencing the germination, growth, and development of plants around the world [21-24].

Weak (low) magnetic fields can be produced using different methods under laboratory conditions.

Low-frequency magnetic fields are mainly related to the electric power supply, through the use of alternating current (AC), where the frequency is often $50-60 \mathrm{~Hz}$.

The fact that a magnetic field with relatively low intensity may impact germination and shoot growth was proven in 1963 by experiments on several cereals: common wheat (Triticum aestivum L.), barley (Hordeum vulgare L.), oat (Avena sativa L.), rye (Secale cereale L.), and on Linum usitatissimum L. [22,25].

Negative consequences of treating plants with a magnetic field were also reported, as well as deterioration of traits associated with the growth and development of plants after reduced exposure dose or complete, artificial removal of the magnetic field from the plant environment [22,26-29]. The positive impact of the magnetic field was determined for several plants, e.g., for the mung bean (Vigna radiata) [30], chickpea (Cicer arietinum) [22,31], wheat (Triticum sp.) [32], corn (Zea mays) [33], tomato (Solanum lycopersicum) [34], okra (Abelmoschus esculentus) [35], rice (Oryza sativa) [36], papaya (Carica papaya), kiwi (Actinidia deliciosa) [37], and empress trees (Paulownia tomentosa and Paulownia fortune) [38]. Interestingly, in a study from 1977, a response of oat (Avena sativa L.) to magnetic pre-sowing stimulation was not obtained in contrast to barley (Hordeum vulgare L.) and common wheat (Triticum aestivum L.) seed [39]. Tests carried out on various wheat cultivars demonstrated that treatment with a magnetic field not only increased the germination rate and percentage, and accelerated plant growth, but it also increased protein content in comparison with the control group [40].

Processing with a magnetic field resulted in increased alpha-amylase activity and content of soluble sugars in zinnia (Zinnia elegans) [41]. In a study on the impact of a low-frequency magnetic field on bitter melon (Momordica charantia), an increased content of chlorophyll and mineral components was reported in comparison to the control group [42].

There is still no clear explanation as to how magnetic fields affect and stimulate seed germination and seedling, but there are some theories advanced by researchers that provide potential explanations of the magnetic field effects. All processes in plants are linked to the movement of $\mathrm{Ca}^{2+}$ ions within the cell. A change in the concentration of $\mathrm{Ca}^{2+}$ ions (and others) within the cell or across the membrane can alter the speed and activities of above these processes in plants. Magnetic field stimulation makes important changes, like changes in the concentration of $\mathrm{Ca}^{2+}$ ions and other ionic densities within the cell or across the membrane. Most theories suggest that biochemical changes occur due to exposing seeds to a magnetic field, as these changes do not occur in controlled untreated seeds [43].

Thus, a magnetic field alters the membrane structure of the plant cells so that the plants, for example, absorb more water and nutrients. The vast majority of biological substances are proteins that contain metal ions, such as hemoglobin, cytochrome, or ferritin, which can be paramagnetic [44].

Avena sativa L., which is common oat, is classified in the grass family (Poaceae) in the order Poales. The plant was introduced to Europe as a weed in wheat and barley cultures. The oldest traces of oat-bristle oat (Avena strigosa)—originated from the Bronze Age in Switzerland, then common wild oat (Avena fatua) and common oat (A. sativa) appeared. Oat cultivation and cultivars began in Poland in the 8th and 9th century, and at the end of the 19th century, varieties were bred [45]. At present, 26 cultivars of non-hulled oat (A. sativa) and five cultivars of hulless oat (A. nuda) are registered in Poland [46].

Oat is a valuable cereal and an excellent source of nutrients $[47,48]$. The plant contains bioactive compounds widely used in medicine, pharmacy, and cosmetology. According to European provisions, oat is included on the list of gluten-free components, although the safety of its consumption by coeliac disease patients remains disputable [49,50].

The chemical composition of the grain determines its nutritional value and one of its most important components is a protein characterized by high biological value (due to the presence of exogenous amino acids). Oat contains many essential amino acids (methionine, cysteine, threonine, isoleucine, tryptophan, valine, leucine, histidine, methionine, phenylalanine, and tyrosine) [51,52]. The protein content in oat grain ranges between approximately $9.46 \%$ and $16.7 \%$ [53], and, according to certain 
studies [48], may reach 19.3\%. The predominant fraction of protein in oat is comprised of globulins (approximately $50 \%-80 \%$ of protein mass), and prolamins and glutelins, approximately $20 \%-25 \%$. Hydrolysates of these proteins demonstrate varied species and cultivar dependent anti-oxidative properties [54]. The fat content, which has a mean of $4.36 \%$, is another characteristic of oat seed in comparison to other cereals [53]. The diversity of oil content in grains between individual cultivars is considerable $(2.7 \%-8.1 \%)$. The main fatty acids in oat oil are linoleic and oleic [48]. Oat grain has a higher protein and fat content, but a lower content of carbohydrates, among which starch is predominant. The content of starch as the most important reserve substance of cereals, and, on average, in oat grains, amounts to approximately $37.5 \%$. Carbohydrates also include fiber (dietary fiber), which accounts for $30 \%$ of oat grain husk (11\%-14\% less after hulling) (Kordulasińska et al. 2014 [53]).

The literature contains variable, sometimes even conflicting, data on the reaction of oats on the use of biostimulators and its foliar treatment. The impact of multi-component foliar fertilizers on yield and chemical composition of non-hulled oats was investigated, and the results show that individual cultivars reacted differently to the effect of fertilizers. The application of a fertilizer did not significantly modify the chemical composition of oat cultivars [55].

The literature contains scant information on the impact of $A$. nodosum algae (or their commercial preparations) on oat yield and composition. Foliar fertilizers caused reduced protein content and increased fat content in oat grain. This result was particularly pronounced after the application of Bio-Algeen S-90 [56].

An increase in total protein is possible in oat grain under conditions of significant sowing delay-occurring typically in the case of a marked yield reduction [57].

In our study, the objective was to determine the influence of Ascophyllum nodosum algae application and pre-sowing stimulation with a low-frequency magnetic field on the mineral and organic composition of oat grain, and investigating the interactions between these factors in forming a chemical composition of oat, under the conditions of a field experiment. A hypothesis was assumed, stating that application of Ascophyllum algae as a biostimulant and a source of micronutrients in combination with subjecting the seeds to pre-sowing stimulation with the low-frequency magnetic field would lead to qualitative changes in oat Avena sativa L. grain.

\section{Materials and Methods}

A strict three-year field experiment with oat cultivar Bingo was carried out in 2016-2018 on heavy soil of IIIa quality class with acid $\mathrm{pH}$ in the township of Krasne $\left(50^{\circ} 30^{\prime} \mathrm{N} ; 22^{\circ} 06^{\prime} \mathrm{E}\right)$. The manganese and iron content in the soil before the experiment was moderate, and the boron, zinc, and copper content was low.

The bioavailable elemental content in the soil for 2016 was $10.4 \mathrm{~g} \cdot \mathrm{kg}^{-1}$ of phosphorus, $23.5 \mathrm{~g} \cdot \mathrm{kg}^{-1}$ of potassium, $3.4 \mathrm{~g} \cdot \mathrm{kg}^{-1}$ for magnesium, $0.5 \mathrm{mg} \cdot \mathrm{kg}^{-1}$ of boron, $135 \mathrm{mg} \cdot \mathrm{kg}^{-1}$ of manganese, $3.4 \mathrm{mg} \cdot \mathrm{kg}^{-1}$ of copper, $6.5 \mathrm{mg} \cdot \mathrm{kg}^{-1}$ of zinc, and $1210 \mathrm{mg} \cdot \mathrm{kg}^{-1}$ of iron.

The bioavailable elemental content in the soil for 2017 was $13.8 \mathrm{~g} \cdot \mathrm{kg}^{-1}$ for phosphorus, $22.0 \mathrm{~g} \cdot \mathrm{kg}^{-1}$ for potassium, $3.4 \mathrm{~g} \cdot \mathrm{kg}^{-1}$ for magnesium, $3.1 \mathrm{~g} \cdot \mathrm{kg}^{-1}$ of manganese, $0.75 \mathrm{mg} \cdot \mathrm{kg}^{-1}$ of boron, $142.5 \mathrm{mg} \cdot \mathrm{kg}^{-1}$ of manganese, $3.5 \mathrm{mg} \cdot \mathrm{kg}^{-1}$ of copper, $6.7 \mathrm{~g} \cdot \mathrm{kg}^{-1}$ of zinc, and $1219 \mathrm{~g} \cdot \mathrm{kg}^{-1}$ for iron.

The bioavailable elemental content in the soil for 2018 was $13.5 \mathrm{mg} \cdot \mathrm{kg}^{-1}$ of phosphorus, $17.0 \mathrm{~g} \cdot \mathrm{kg}^{-1}$ of potassium, $2.8 \mathrm{~g} \cdot \mathrm{kg}^{-1}$ of magnesium, $0.7 \mathrm{mg} \cdot \mathrm{kg}^{-1}$ of boron, $125.5 \mathrm{mg} \cdot \mathrm{kg}^{-1}$ of manganese, $3.2 \mathrm{mg} \cdot \mathrm{kg}^{-1}$ of copper, $6 \mathrm{mg} \cdot \mathrm{kg}^{-1}$ of zinc, and $1225 \mathrm{mg} \cdot \mathrm{kg}^{-1}$ of iron.

Cereals: spring barley in the first year of the experiment and spring wheat in second and third year was the pre-crop for oat. A traditional cultivation system was applied. Mineral fertilizers were sown every year in the form of superphosphate and potassium salt (at a dosage of $100 \mathrm{~kg} \mathrm{~K}_{2} \mathrm{O} \cdot \mathrm{ha}^{-1}$ and $80 \mathrm{~kg} \mathrm{P} \mathrm{P}_{2} \mathrm{O}_{5} \cdot \mathrm{ha}^{-1}$ ) and ammonium nitrate-nitrogen in ammonium form $\left(\mathrm{N}-\mathrm{NH}_{4}\right)$ and nitrate form $\left(\mathrm{N}-\mathrm{NO}_{3}\right)$ at a dosage of $80 \mathrm{~kg} \cdot \mathrm{ha}^{-1}$. The oat seed was sown with an SPZ 020 suspended seed drill at a density of 550 grains per square meter. Weeds were eliminated using Chwastox Turbo $340 \mathrm{SL}$ herbicide (MCPA), and the Karate Zeon 050 CS preparation was used against the cereal leaf beetle. 
Sowing dates were as follows: 5 April 2016, 4 April 2017, and 11 April 2018. Harvest dates were 18 August 2016, 10 August 2017, and 8 August 2019.

Algae biomass fertilization was applied at 3 levels in doses containing the following:

A0: control (null dose);

A1: $3.2 \mathrm{~g} \cdot \mathrm{ha}^{-1}$ boron, $2.5 \mathrm{~g} \cdot \mathrm{ha}^{-1}$ manganese, $2.1 \mathrm{~g} \cdot \mathrm{ha}^{-1}$ copper, $6.2 \mathrm{~g} \cdot \mathrm{ha}^{-1}$ zinc, and $0.43 \mathrm{~kg} \cdot \mathrm{ha}^{-1}$ iron; A2: $6.4 \mathrm{~g} \cdot \mathrm{ha}^{-1}$ boron, $5 \mathrm{~g} \cdot \mathrm{ha}^{-1}$ manganese, $4.2 \mathrm{~g} \cdot \mathrm{ha}^{-1}$ copper, $12.4 \mathrm{~g} \cdot \mathrm{ha}^{-1} \mathrm{zinc}$, and $0.86 \mathrm{~kg} \cdot \mathrm{ha}^{-1}$ iron.

The factor was applied to the leaves in the form of 2- and 4-fold spraying during the tillering and stalk shooting phases.

On the day of sowing, the seeds were exposed to a $50 \mathrm{mT}$ magnetic field at $50 \mathrm{~Hz}$ over $\mathrm{P} 0-0 \mathrm{~s}$ (control), P1-6 s, and P2-60 s. The seeds were exposed to a magnetic field through the use of an air-spaced coil with an inner diameter of $11 \mathrm{~cm}$ and a length of $15 \mathrm{~cm}$. The induction coil was powered by a single-phase AC (alternating current) source. The calculations of such coil parameters as resistance, inductance, reactance, impedance, the intensity of the current flowing in the coil, and the strength of the magnetic field in the central point of the coil were carried out using a technical method of computing based on Ampere's law.

Figure 1 shows the station used for magnetic field stimulation, the model of distribution of the magnetic field in the applied solenoid, and the content parameters for the induction of the magnetic field.
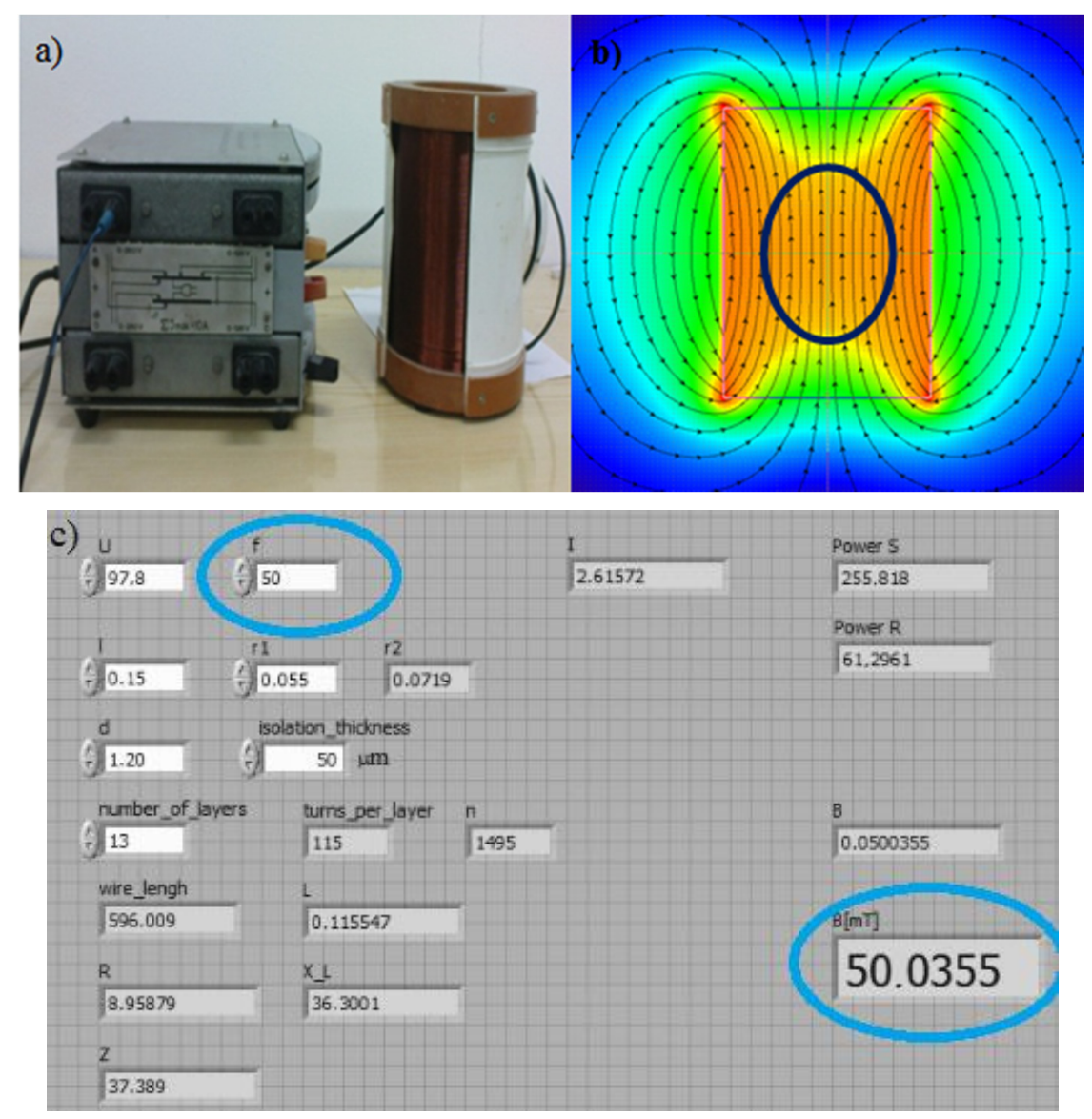

Figure 1. (a) Station for performing stimulation with a slowly-changing, low-frequency $50 \mathrm{mT}$ magnetic field. (b) Model distribution of magnetic field in the applied solenoid. (c) Counter circuit parameters at the proposed induction of a magnetic field (f-frequency, B-induction).

Objects (combinations of factors) were repeated in four replications every year. Table 1 lists the description of the culture conditions. 
Table 1. Samples and the description of culture conditions.

\begin{tabular}{ccc}
\hline No & Name of Sample & Description of Objects \\
\hline 1 & A0P0 & no fertilizer (A0), no magnetostimulation (P0) \\
\hline 2 & A0P1 & no fertilizer (A0), short magnetostimulation (P1) \\
\hline 3 & A0P2 & no fertilizer (A0), longer magnetostimulation (P2) \\
\hline 4 & A1P0 & average dose of algae (A1), no magnetostimulation (P0) \\
\hline 5 & A1P1 & average dose of algae (A1), short magnetostimulation (P1) \\
\hline 6 & A1P2 & average dose of algae (A1), longer magnetostimulation (P2) \\
\hline 7 & A2P0 & maximum dose of algae (A2), no magnetostimulation (P0) \\
\hline 8 & A2P1 & maximum dose of algae fertilizer (A2), short magnetostimulation (P1) \\
\hline 9 & A2P2 & maximum dose of algae fertilizer (A2), longer magnetostimulation (P2) \\
\hline
\end{tabular}

The study material for laboratory (analytical) testing consisted of oat grain ground in a ZM 200 laboratory mill with a $1 \mathrm{~mm}$ mesh. Protein content was measured on a CHN (Carbon Hydrogen \& Nitrogen) TruSpec analyzer by LECO (LECO Corporation, Saint Joseph, MI, USA). The rest of the organic composition of oat was measured stereoscopically. Measurements of fat and raw fiber content were performed on the FT-NIR (Fourier Transform Near-Infrared Spectroscopy) analyzer MPA (Multi-Purpose Analyzer) by Bruker. The content of nitrogen-free extract (NFE) (remaining organic compounds of vegetable origin) was calculated by deducting the content of total protein, raw fat, fiber, and ash from $100 \%$.

The FT-Raman spectra of the oat grain endosperm were registered via the Nicolet NXR 9650 FT-Raman spectrometer equipped with an Nd:YAG laser $(1064 \mathrm{~nm})$ and germanium detector. The measurements were conducted in the range from 150 to $3700 \mathrm{~cm}^{-1}$ with a laser power of $1 \mathrm{~W}$, using an out-of-focus laser beam with a diameter of approximately $100 \mu \mathrm{m}$ and spectral resolution of $8 \mathrm{~cm}^{-1}$. The Raman spectra were processed via the Omnic/Thermo Scientific software. From each sample group, e.g., A0P0, ten oat grains were measured, and the average spectrum form these measurements was placed in the paper. For each spectrum baseline, correction and vector normalization were done. To determine the similarity, and, at the same time, the ability to distinguish between groups, principal component analysis (PCA) was performed for the FT-Raman region between $800 \mathrm{~cm}^{-1}$ and $1800 \mathrm{~cm}^{-1}$. This region is called the "fingerprint region", which means that each substance has its unique spectrum in this range.

The grains were mineralized with nitric acid using a microwave mineralizator (Ultrawave, Milestone Ethos-One, Sorisole (BG), Italy) for $30 \mathrm{~min}$. A clear solution volume was prepared for each sample using deionized water. The quantitative determination of elements was carried out by Optical Emission Spectrometry with Inductively Induced Plasma (ICP-OES) using Thermo iCAP6500 (Thermo Fisher Scientific Inc., Schaumburg, IL, USA).

Principal Component Analysis (PCA) was done using the Past 3.0 software using the average spectra of samples. PCA is a non-parametric method for extracting relevant information from confusing data sets, allowing us to identify patterns in data and to highlight their similarities and differences. PCA reduces the dimensionality and the number of variables of the data by maintaining as much variance as possible. To better illustrate the Raman spectroscopy method, Figure 2 shows a camera preview-a laser beam focused on the center of oat grain endosperm.

Testing results were subject to statistical analyses. A two-way analysis of variance was carried out using the Statistica software to assess the influence of the tested factors on grain chemical composition. The significance of differences between means for objects and between years was examined using the Tukey multiple comparison test at the significance level of $\alpha=0.05$. Variability between years was tested via two-way ANOVA. Homogenous groups were determined by the Tukey's Honest Significant Difference test. 


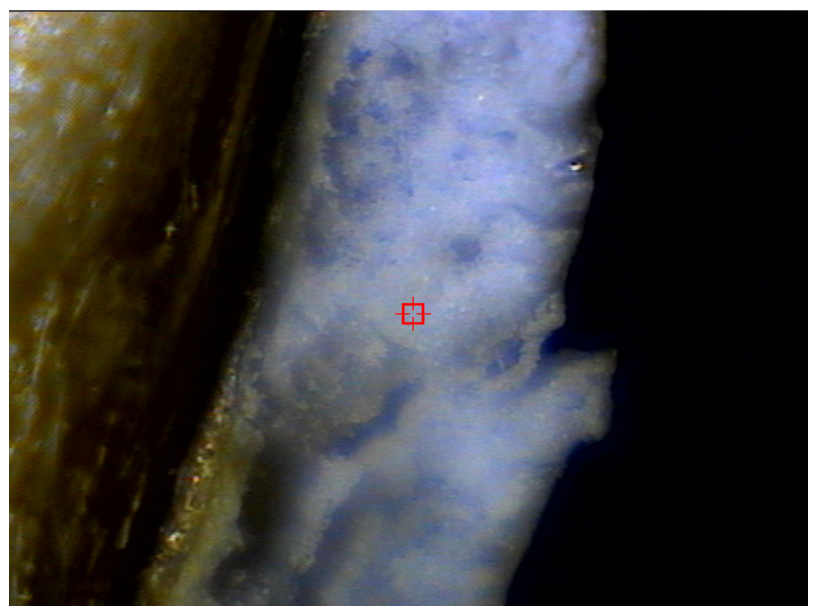

Figure 2. Camera preview with a focus point on the laser beam (red square).

\section{Results}

\subsection{Organic Composition and Ash Content}

The mean protein content (Figure 3) in 2016-2018 in dry weigh of oat grain was $116.7 \mathrm{~g} \cdot \mathrm{kg}^{-1}$. The lowest grain protein content was found in 2017 (mean of 10.38\% of the protein in dry weight (d.w.)), whereas the highest was found in 2016 (13.13\% d.w.). The protein content was not modified by the magnetic stimulation factor, nor by the interactions between both factors; however, a statistically significant influence of the A factor was observed on the mean percentage of grain protein content for the 2016-2018 period. Algae application at the highest dose resulted in a reduction of its content by $2.61 \%$.

\section{Protein contents}

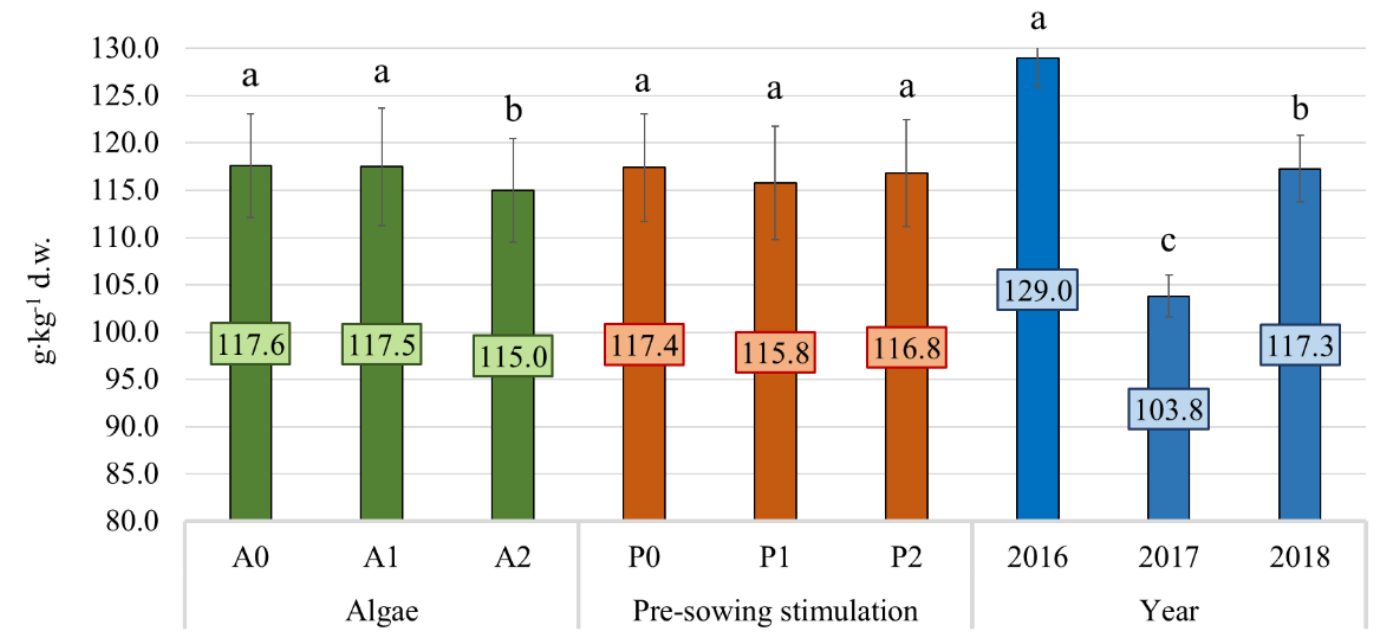

Figure 3. The mean protein content of oat grains in 2016-2018, depending on the experimental factors used. According to Tukey's Honest Significant Difference (HSD) test, the means marked with the same letter are not significantly different at $\alpha \leq 0.05$.

The average content of crude fat (Figure 4) from all years of the experiment was 3.89\% d.w. (approximately $39 \mathrm{~g} \cdot \mathrm{kg}^{-1}$ ). The highest percentage of raw fat in grain dry weight was recorded for 2017 (4.17), the lowest (3.53) in 2016. The difference was statistically significant. The content of raw fat in the oat grain did not differ between the objects; however, a significant interaction between factors in the formation of fat content was observed in the 2016 season. 


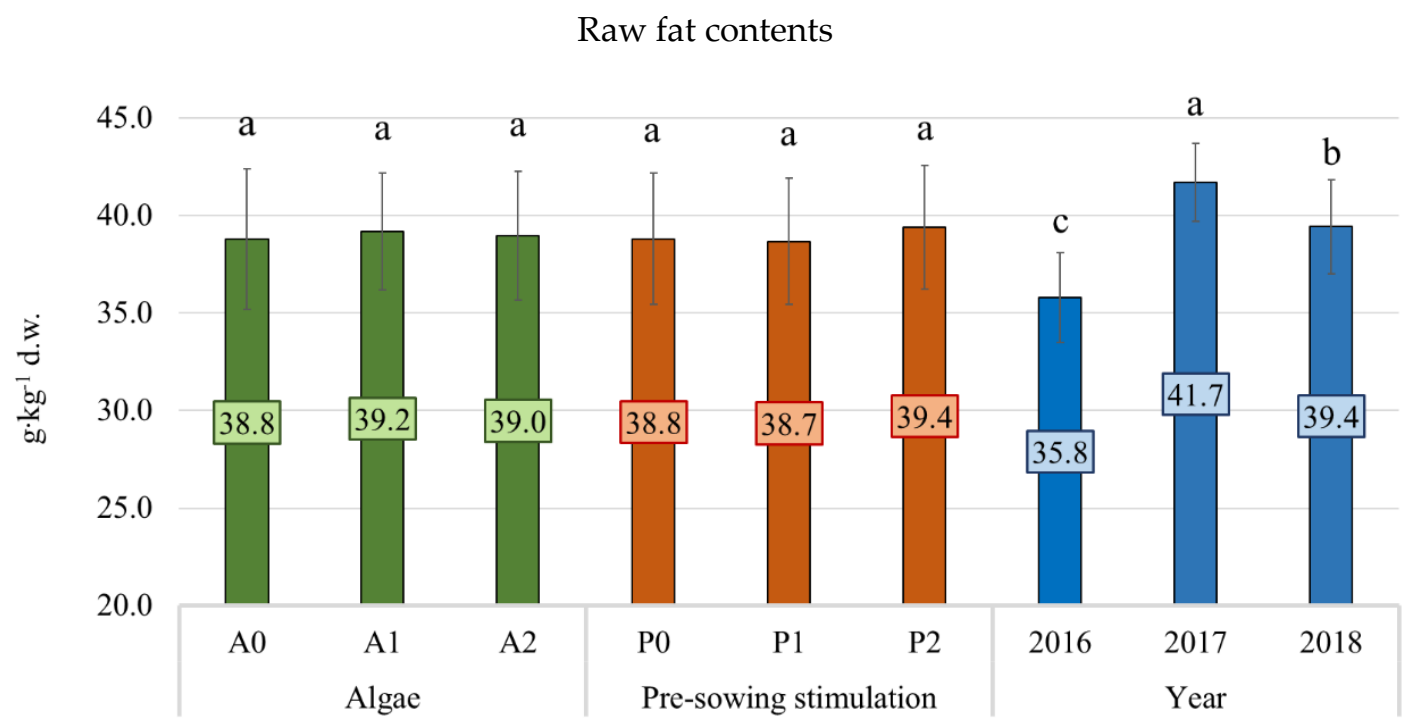

Figure 4. The mean crude fat content of protein in oat grains in 2016-2018, depending on the experimental factors used. According to Tukey's HSD test, means marked with the same letter are not significantly different at $\alpha \leq 0.05$.

The content of raw fiber in dry weight (Figure 5) of oat grain was on average $118.3 \mathrm{~g} \cdot \mathrm{kg}^{-1}$ $(11.83 \%$ d.w.). Its highest content was recorded in 2018 (12.14\% d.w.), the lowest in $2016(11.28 \%)$. The content of raw fiber in the grain was not differentiated by the experimental factors; however, it was statistically significantly differentiated in the yearly results.

Raw fiber contents

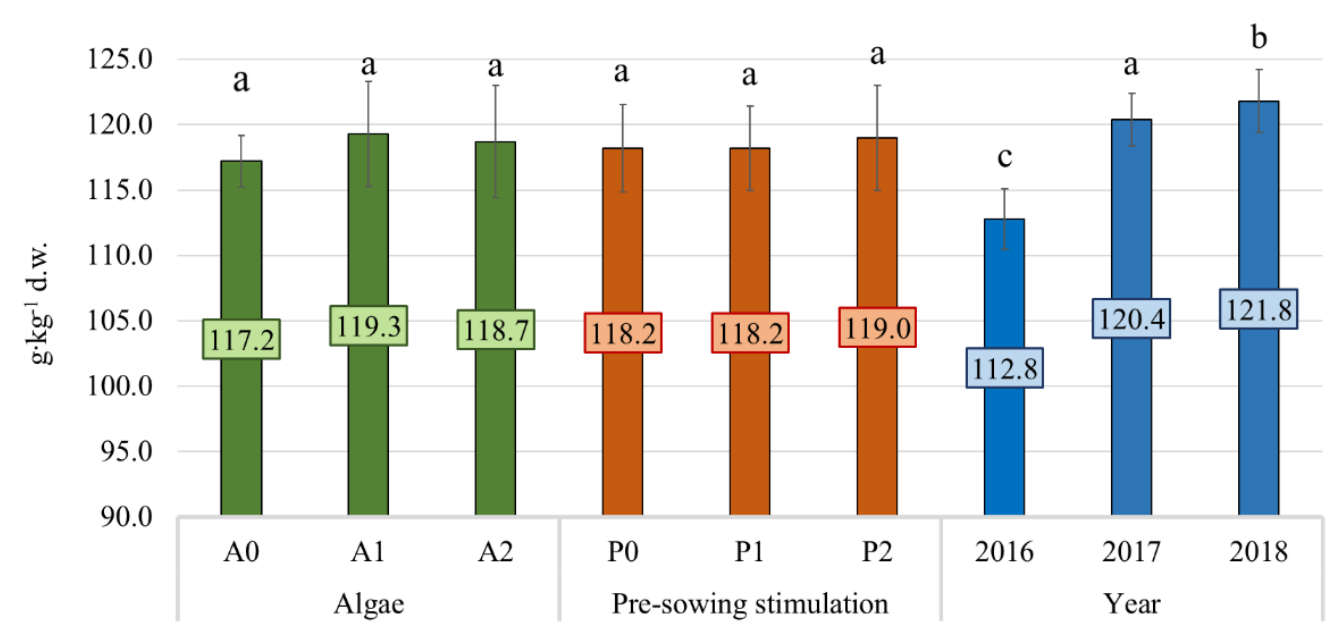

Figure 5. The mean raw fiber content of protein in oat grains in 2016-2018 depending on the experimental factors used. According to Tukey's HSD test, the means marked with the same letter are not significantly different at $\alpha \leq 0.05$.

The average ash content (Figure 6) in the grain from 2016-2018 was $26 \mathrm{~g} \cdot \mathrm{kg}^{-1}(2.6 \%)$.

The ash content in oat grain was also determined by the year of the experiment: the highest amount of ash was present in the grain in 2016 (2.82\%) and the lowest in $2017(2.23 \%)$. 


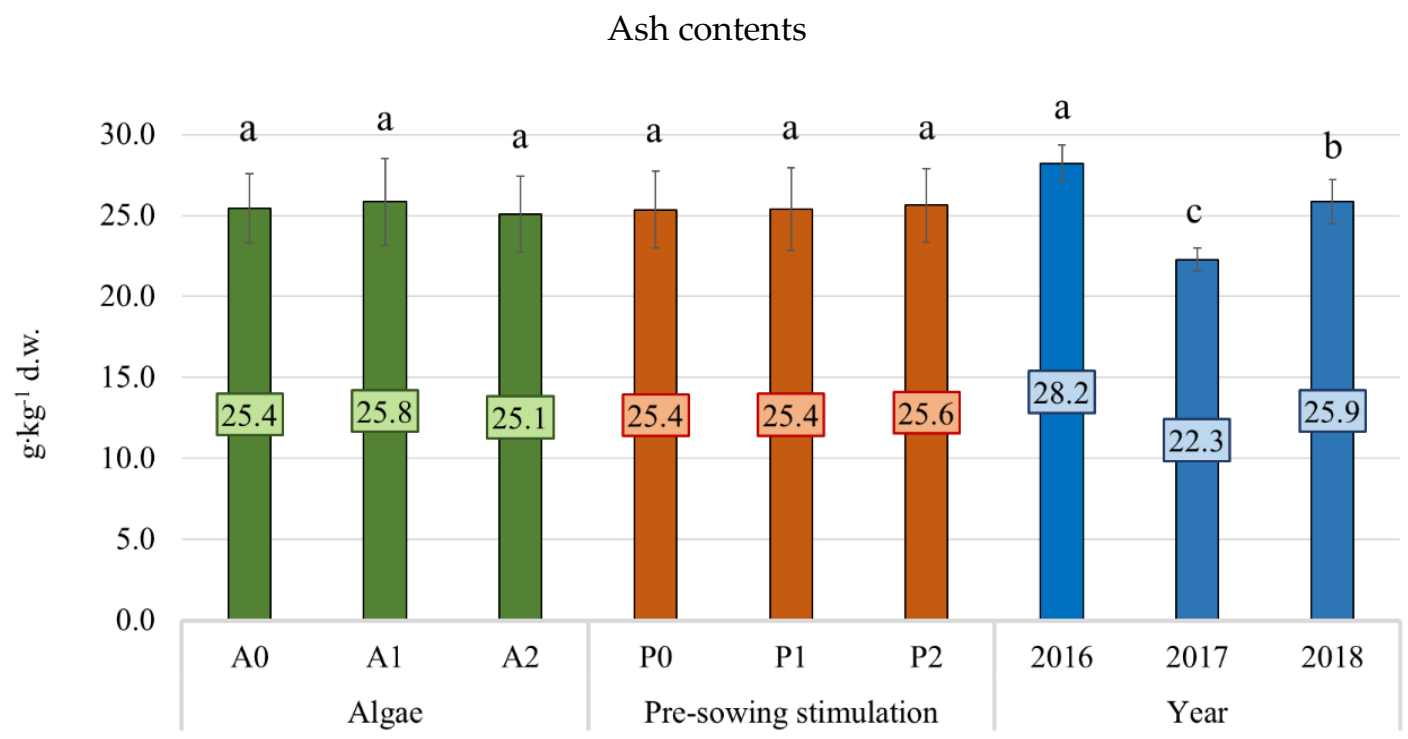

Figure 6. The mean ash content of protein in oat grains in 2016-2018 depending on the experimental factors used. According to Tukey's HSD test, the means marked with the same letter are not significantly different at $\alpha \leq 0.05$.

The content of nitrogen-free extract (NFE, Figure 7) in oat grain in the 2016-2018 period was on average $624 \mathrm{~g} \cdot \mathrm{kg}^{-1}(62.4 \%$ d.w.), attaining its highest level in the 2017 season $(63,71 \%$ d.w.). No significant differences in the result between its objects could be determined. Statistically significant differences in the results for 2017 were found.

NFE contents

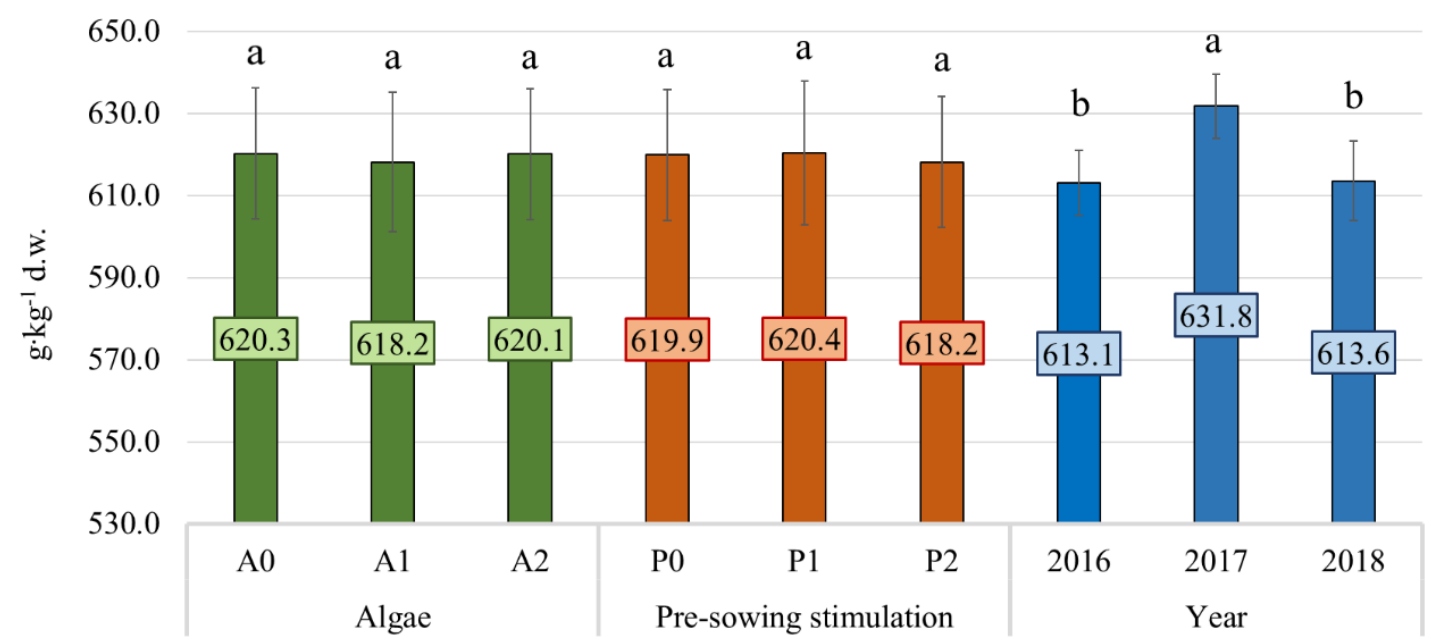

Figure 7. The mean raw fiber content of protein in oat grains in 2016-2018 depending on the experimental factors used. According to Tukey's HSD test, the means marked with the same letter are not significantly different at $\alpha \leq 0.05$.

\subsection{Content of Microemelents, Macro-Ingredients, and Trace Elements}

Table 2 shows the mean potassium, phosphorus, magnesium, sulfur, and calcium content. 
Table 2. The average potassium $(\mathrm{K})$, phosphorus $(\mathrm{P})$, magnesium $(\mathrm{Mg})$, sulfur $(\mathrm{S})$, and calcium $(\mathrm{Ca})$ content $\left(\mathrm{g} \cdot \mathrm{kg}^{-1}\right)$ in oat grain depending on the combination of algae fertilization and magnetic field stimulation in 2016-2018.

\begin{tabular}{|c|c|c|c|c|c|c|c|c|c|c|}
\hline Macro-Element g.kg ${ }^{-1}$ & Year & & & & & Object & & & & \\
\hline & & A0P0 & A0P1 & A0P2 & A1P0 & A1P1 & A1P2 & A2P0 & A2P1 & A2P2 \\
\hline \multirow{3}{*}{ K } & 2016 & $4.03 \pm 0.16$ & $4.11 \pm 0.20$ & $4.11 \pm 0.18$ & $4.14 \pm 0.20$ & $3.90 \pm 0.19$ & $3.93 \pm 0.21$ & $3.99 \pm 0.17$ & $4.01 \pm 0.22$ & $30.96 \pm 0.23$ \\
\hline & 2017 & $4.44 \pm 0.20$ & $4.33 \pm 0.19$ & $4.06 \pm 0.24$ & $4.40 \pm 0.20$ & $4.36 \pm 0.23$ & $4.28 \pm 0.21$ & $4.22 \pm 0.15$ & $4.42 \pm 0.22$ & $4.49 \pm 0.31$ \\
\hline & 2018 & $4.14 \pm 0.21$ & $4.14 \pm 0.19$ & $3.91 \pm 0.15$ & $4.16 \pm 0.19$ & $4.37 \pm 0.17$ & $3.93 \pm 0.18$ & $3.99 \pm 0.16$ & $4.03 \pm 0.18$ & $3.82 \pm 0.18$ \\
\hline \multirow{3}{*}{$\mathrm{P}$} & 2016 & $3.85 \pm 0,25$ & $3.66 \pm 0.14$ & $3.85 \pm 0.22$ & $3.79 \pm 0.20$ & $4.01 \pm 0.14$ & $3.33 \pm 0.22$ & $3.72 \pm 0.20$ & $3.73 \pm 0.17$ & $3.66 \pm 0.20$ \\
\hline & 2017 & $3.72 \pm 0.20$ & $3.63 \pm 0.17$ & $3.34 \pm 0.18$ & $3.62 \pm 0.12$ & $3.70 \pm 0.19$ & $3.47 \pm 0.20$ & $3.51 \pm 0,15$ & $3.69 \pm 0.23$ & $3.44 \pm 0.13$ \\
\hline & 2018 & $3.98 \pm 0.21$ & $4.04 \pm 0.12$ & $4.13 \pm 0.23$ & $3.94 \pm 0.18$ & $4.40 \pm 0.30$ & $3.72 \pm 0.18$ & $3.93 \pm 0.25$ & $3.97 \pm 0.20$ & $3.87 \pm 0.22$ \\
\hline \multirow{3}{*}{$\mathrm{Mg}$} & 2016 & $1.28 \pm 0.19$ & $1.32 \pm 0.04$ & $1.31 \pm 0.08$ & $1.34 \pm 0.08$ & $1.35 \pm 0,10$ & $1.29 \pm 0.04$ & $1.25 \pm 0.08$ & $1.21 \pm 0.12$ & $1.37 \pm 0.12$ \\
\hline & 2017 & $2.07 \pm 0,09$ & $1.88 \pm 0.10$ & $1.86 \pm 0.08$ & $1.94 \pm 0.05$ & $1.98 \pm 0.12$ & $0.97 \pm 0.10$ & $1.97 \pm 0.12$ & $1.95 \pm 0.10$ & $1.93 \pm 0.13$ \\
\hline & 2018 & $1.28 \pm 0.12$ & $1.34 \pm 0.09$ & $1.26 \pm 0,11$ & $1,30 \pm 0,06$ & $1.68 \pm 0.11$ & $118 \pm 0.07$ & $1,25 \pm 0.09$ & $1,25 \pm 0.09$ & $1.15 \pm 0.07$ \\
\hline \multirow{3}{*}{ S } & 2016 & $1.59 \pm 0,14$ & $1.56 \pm 0,10$ & $1.61 \pm 0,06$ & $1.62 \pm 0.11$ & $1.66 \pm 0.08$ & $1.56 \pm 0.09$ & $1.52 \pm 0.07$ & $1.55 \pm 0.08$ & $1.73 \pm 0.12$ \\
\hline & 2017 & $1.26 \pm 0.09$ & $1.37 \pm 0.11$ & $1.29 \pm 0.09$ & $1.32 \pm 0.08$ & $1.32 \pm 0.12$ & $1.29 \pm 0.06$ & $1.28 \pm 0.07$ & $1.36 \pm 0.12$ & $1.28 \pm 0.08$ \\
\hline & 2018 & $1.46 \pm 0.07$ & $1.58 \pm 0.13$ & $1.39 \pm 0.09$ & $1.32 \pm 0.06$ & $1.87 \pm 0.07$ & $1.33 \pm 0.07$ & $1.39 \pm 0.06$ & $1.44 \pm 0.10$ & $1.30 \pm 0.11$ \\
\hline \multirow{3}{*}{$\mathrm{Ca}$} & 2016 & $1.06 \pm 0.09$ & $1.21 \pm 0.06$ & $1.21 \pm 0.11$ & $1.16 \pm 0.16$ & $1.09 \pm 0.03$ & $1.13 \pm 0.05$ & $1.27 \pm 0.09$ & $1.08 \pm 0.05$ & $1.08 \pm 0.04$ \\
\hline & 2017 & $1.23 \pm 0.06$ & $1.02 \pm 0.08$ & $0.99 \pm 0.04$ & $0.95 \pm 0.05$ & $0.99 \pm 0.05$ & $1.15 \pm 0.08$ & $1.07 \pm 0.04$ & $1.04 \pm 0.06$ & $1.02 \pm 0.08$ \\
\hline & 2018 & $1.35 \pm 0.13$ & $1.20 \pm 0.11$ & $1.20 \pm 0.04$ & $1.13 \pm 0.10$ & $1.30 \pm 0.05$ & $1.21 \pm 0.04$ & $0.93 \pm 0.08$ & $0.94 \pm 0.04$ & $1.04 \pm 0.12$ \\
\hline
\end{tabular}


The mean potassium content in oat grain throughout the experiment was $4.14 \mathrm{~g} \cdot \mathrm{kg}^{-1}$. The highest content of potassium in grain was found in $2017\left(4.34 \mathrm{~g} \cdot \mathrm{kg}^{-1}\right)$, and in 2016 and 2018, the oat grain content was 4.02 and $4.05 \mathrm{~g} \cdot \mathrm{kg}^{-1}$, respectively. Statistical analysis demonstrated the absence of statistically significant differences in the content of potassium in grain between the tested objects.

The mean content of phosphorus from three years of study of the analyzed objects was $3.79 \mathrm{~g} \cdot \mathrm{kg}^{-1}$. The highest content of this macronutrient was recorded for $2018\left(4.06 \mathrm{~g} \cdot \mathrm{kg}^{-1}\right)$, and in the preceding years, 3.73 and $3.57 \mathrm{~g} \cdot \mathrm{kg}^{-1}$, respectively. The variability between the objects in terms of phosphorus content was not statistically significant.

The mean magnesium content from three years of the experiment was $1.48 \mathrm{~g} \cdot \mathrm{kg}^{-1}\left(1.30 \mathrm{~g} \cdot \mathrm{kg}^{-1}\right.$ for 2016 and 2018 and $1.83 \mathrm{~g} \cdot \mathrm{kg}^{-1}$ for the 2017 season). No statistically significant influence of the tested factors on the content of this element in oat grain could be found in the conducted experiment. The magnesium content in the tested oat grain samples was differentiated by season-its highest concentration was found in 2017.

The application of algae fertilization and pre-sowing stimulation with a low-frequency magnetic field did not lead to significant changes in sulfur content, which remained at an average level $\left(1.46 \mathrm{~g} \cdot \mathrm{kg}^{-1}\right)$ the entire duration. The mean for 2016, 2017, and 2018 was $1.60 \mathrm{~g} \cdot \mathrm{kg}^{-1}, 1.31 \mathrm{~g} \cdot \mathrm{kg}^{-1}$, and $1.48 \mathrm{~g} \cdot \mathrm{kg}^{-1}$, respectively. A tendency was observed in 2017 for lower sulfur content when the grain was observed in contrast to 2016 and 2018. Its highest content was determined in the A1P1 object; however, the difference was not statistically significant. The tested factors did not exercise a significant impact on the content of macronutrients in oat grain.

The lowest calcium content was determined for oat grain in 2017-1.05 g. $\mathrm{kg}^{-1}$. In 2016 and 2018, this content was (mean from all objects) $1.15 \mathrm{~g} \cdot \mathrm{kg}^{-1}$, which resulted in a three-year mean of $1.11 \mathrm{~g} \cdot \mathrm{kg}^{-1}$. A significant tendency to calcium content reduction in the grain was observed with an increasing dose of applied algae $\left(1.16 \mathrm{~g} \cdot \mathrm{kg}^{-1}\right.$ at the A0 level—control, $1.12 \mathrm{~g} \cdot \mathrm{kg}^{-1}$ for a dose at the A1 level, and $1.05 \mathrm{~g} \cdot \mathrm{kg}^{-1}$ for a dose at the A2 level in the three-year average). Figure 8 shows the calcium content in oat grains depending on the experimental factors used.

\section{Calcium contents}

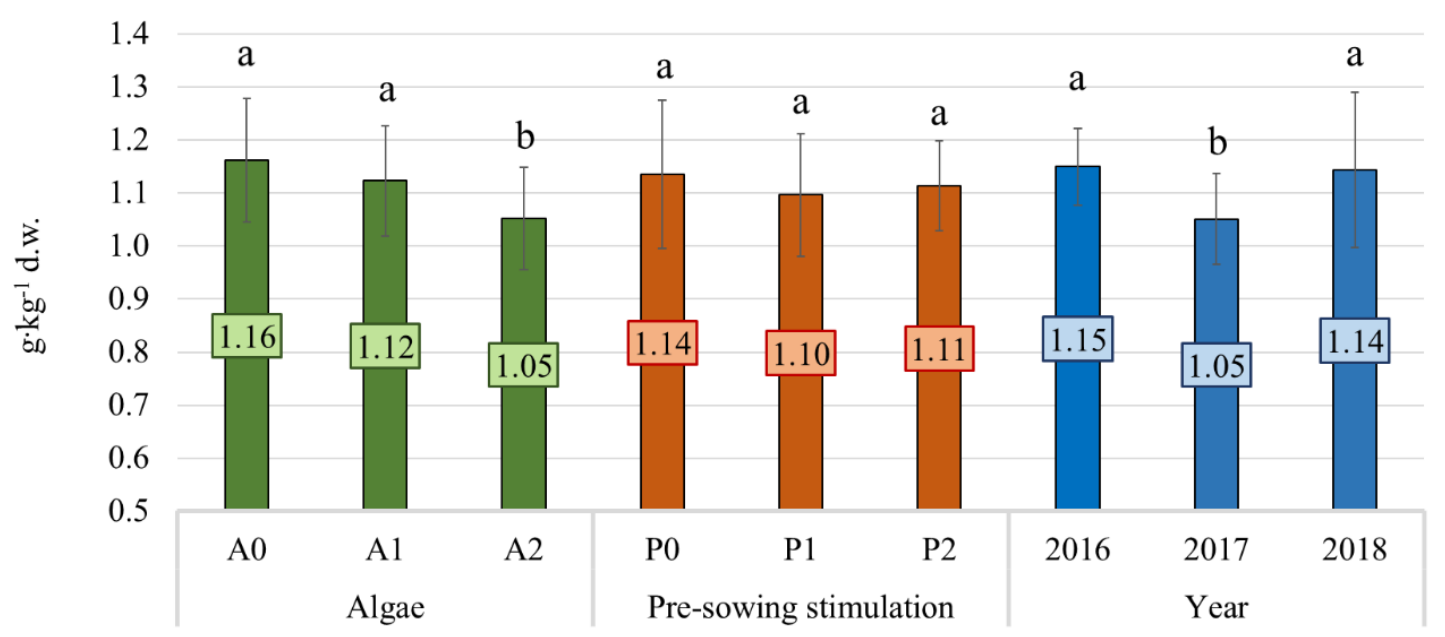

Figure 8. The mean calcium content $\left(\mathrm{g} \cdot \mathrm{kg}^{-1}\right)$ in oat grains in 2016-2018 depending on the experimental factors used. According to Tukey's HSD test, the means marked with the same letter are not significantly different at $\alpha \leq 0.05$.

Factors and different years of experience had different influences on the content of microelements in oat grains.

The average content of copper (Table 3) in oat grain from all objects was $3.15 \mathrm{mg} \cdot \mathrm{kg}^{-1}$. The content of this element in 2016-2018 was 3.26, 3.30, and $2.90 \mathrm{mg} \cdot \mathrm{kg}^{-1}$, respectively. 
Table 3. The average copper $(\mathrm{Cu})$, iron $(\mathrm{Fe})$, manganese $(\mathrm{Mn})$, sodium $(\mathrm{Na})$, molybdenum $(\mathrm{Mo})$, zinc $(\mathrm{Zn})$, and strontium $(\mathrm{Sr})$ content (mg.kg $\left.{ }^{-1}\right)$ in oat grain depending on the combination of algae fertilization and magnetic field stimulation in 2016-2018.

\begin{tabular}{|c|c|c|c|c|c|c|c|c|c|c|}
\hline Micro-Element $\mathrm{mg} \cdot \mathrm{kg}^{-1}$ & Year & & & & & Object & & & & \\
\hline & & A0P0 & A0P1 & A0P2 & A1P0 & A1P1 & A1P2 & A2P0 & A2P1 & A2P2 \\
\hline \multirow{3}{*}{$\mathrm{Cu}$} & 2016 & $2.0 \pm 0.21$ & $3.00 \pm 0.32$ & $2.90 \pm 0.26$ & $3.16 \pm 0.22$ & $3.49 \pm 0.15$ & $3.50 \pm 0.03$ & $4.49 \pm 0.21$ & $3.25 \pm 0.25$ & $2.72 \pm 0.20$ \\
\hline & 2017 & $4.44 \pm 0.20$ & $4.33 \pm 0.19$ & $4.06 \pm 0.24$ & $4.40 \pm 0.20$ & $4.36 \pm 0.23$ & $4.28 \pm 0.21$ & $4.22 \pm 0.15$ & $4.42 \pm 0.22$ & $4.49 \pm 0.31$ \\
\hline & 2018 & $4.14 \pm 0.21$ & $4.14 \pm 0.19$ & $3.91 \pm 0.15$ & $4.16 \pm 0.19$ & $4.37 \pm 0.17$ & $3.93 \pm 0.18$ & $3.99 \pm 0.16$ & $4.03 \pm 0.18$ & $3.82 \pm 0.18$ \\
\hline \multirow{3}{*}{$\mathrm{Fe}$} & 2016 & $31.16 \pm 0.52$ & $34.01 \pm 4.11$ & $32.87 \pm 2.98$ & $30.73 \pm 1.95$ & $30.23 \pm 0.87$ & $33.17 \pm 2.15$ & $33.27 \pm 1.20$ & $35.77 \pm 0.96$ & $33.27 \pm 0.60$ \\
\hline & 2017 & $30.59 \pm 3.01$ & $31.11 \pm 1.14$ & $32.26 \pm 3.0$ & $29.73 \pm 0.95$ & $29.26 \pm 3.0$ & $33.18 \pm 0.10$ & $36.88 \pm 2.80$ & $37.17 \pm 1.80$ & $35.07 \pm 1.30$ \\
\hline & 2018 & $30.52 \pm 1.11$ & $33.07 \pm 2.0$ & $32.26 \pm 3.0$ & $38.7 \pm 2.02$ & $37.15 \pm 4.15$ & $30.52 \pm 0.25$ & $35.0 \pm 2.50$ & $37.2 \pm 1.60$ & $38.37 \pm 2.20$ \\
\hline \multirow{3}{*}{ Mn } & 2016 & $42.19 \pm 3.97$ & $43.87 \pm 2.35$ & $43.03 \pm 2.25$ & $49.15 \pm 2.24$ & $45.02 \pm 3.87$ & $46.97 \pm 2.95$ & $47.94 \pm 3.98$ & $46.28 \pm 3.05$ & $45.30 \pm 2.40$ \\
\hline & 2017 & $45.19 \pm 4.25$ & $43.87 \pm 1.95$ & $45.07 \pm 3.85$ & $47.14 \pm 2.67$ & $46.02 \pm 2.85$ & $46.97 \pm 5.05$ & $46.30 \pm 2.19$ & $46.61 \pm 3.0$ & $46.47 \pm 4.02$ \\
\hline & 2018 & $40.2 \pm 3.05$ & $42.22 \pm 4.0$ & $42.7 \pm 3.45$ & $47.5 \pm 5.02$ & $46.13 \pm 2.0$ & $41.61 \pm 2.65$ & $41.13 \pm 3.56$ & $41.5 \pm 3.35$ & $42.46 \pm 3.37$ \\
\hline \multirow{3}{*}{$\mathrm{Na}$} & 2016 & $19.94 \pm 1.50$ & $33.87 \pm 2.18$ & $21.94 \pm 1.19$ & $20.64 \pm 2.54$ & $26.97 \pm 4.07$ & $37.92 \pm 1.95$ & $27.03 \pm 1.96$ & $28.52 \pm 3.85$ & $37.31 \pm 4.02$ \\
\hline & 2017 & $24.97 \pm 2.0$ & $25.97 \pm 5.16$ & $23.94 \pm 3.75$ & $23.74 \pm 1.85$ & $26.99 \pm 3.44$ & $27.90 \pm 1.98$ & $26.15 \pm 2.13$ & $25.57 \pm 4.01$ & $27.90 \pm 5.65$ \\
\hline & 2018 & $21.19 \pm 4.05$ & $22.32 \pm 2.05$ & $22.57 \pm 2.50$ & $28.18 \pm 2.75$ & $30.04 \pm 2.22$ & $24.30 \pm 2.86$ & $29.96 \pm 3.15$ & $31.70 \pm 2.15$ & $29.09 \pm 3.04$ \\
\hline \multirow{3}{*}{ Mo } & 2016 & $0.77 \pm 0.04$ & $0.75 \pm 0.08$ & $0.77 \pm 0.02$ & $0.89 \pm 0.04$ & $0.69 \pm 0.06$ & $0.79 \pm 0.03$ & $0.89 \pm 0.04$ & $0.76 \pm 0.06$ & $0.63 \pm 0.06$ \\
\hline & 2017 & $0.74 \pm 0.04$ & $0.72 \pm 0.04$ & $0.71 \pm 0.03$ & $0.83 \pm 0.04$ & $0.69 \pm 0.03$ & $0.79 \pm 0.03$ & $0.76 \pm 0.04$ & $0.78 \pm 0.03$ & $0.74 \pm 0.05$ \\
\hline & 2018 & $0.73 \pm 0.05$ & $0.72 \pm 0.03$ & $0.72 \pm 0.09$ & $0.82 \pm 0.06$ & $0.73 \pm 0.03$ & $0.79 \pm 0.02$ & $0.79 \pm 0.04$ & $0.76 \pm 0.02$ & $0.80 \pm 0.07$ \\
\hline \multirow{3}{*}{$\mathrm{Zn}$} & 2016 & $21.64 \pm 3.95$ & $25.20 \pm 4.06$ & $23.68 \pm 2.00$ & $23.79 \pm 3.65$ & $25.93 \pm 2.11$ & $25.18 \pm 3.05$ & $30.57 \pm 4.01$ & $31.41 \pm 4.44$ & $23.94 \pm 2.50$ \\
\hline & 2017 & $20.63 \pm 3.40$ & $23.51 \pm 5.87$ & $23.10 \pm 2.15$ & $20.66 \pm 1.88$ & $24.33 \pm 4.05$ & $20.13 \pm 5.13$ & $22.05 \pm 2.85$ & $21.79 \pm 2.95$ & $22.08 \pm 1.95$ \\
\hline & 2018 & $24.30 \pm 2.19$ & $27.60 \pm 3.88$ & $28.65 \pm 3.45$ & $24.84 \pm 2.15$ & $27.96 \pm 2.75$ & $30.90 \pm 3.95$ & $33.0 \pm 0.28$ & $28.47 \pm 3.5$ & $30.41 \pm 4.0$ \\
\hline \multirow{3}{*}{$\mathrm{Sr}$} & 2016 & $1.22 \pm 0.35$ & $1.77 \pm 0.10$ & $1.49 \pm 0.21$ & $1.40 \pm 0.08$ & $1.11 \pm 0.04$ & $1.92 \pm 0.14$ & $1.77 \pm 0.05$ & $1.30 \pm 0.06$ & $1.60 \pm 0.06$ \\
\hline & 2017 & $1.21 \pm 0.25$ & $1.76 \pm 0.09$ & $1.52 \pm 0.05$ & $1.40 \pm 0.10$ & $1.18 \pm 0.17$ & $2.06 \pm 0.26$ & $1.61 \pm 0.12$ & $1.64 \pm 0.04$ & $1.70 \pm 0.18$ \\
\hline & 2018 & $1.52 \pm 0.30$ & $2.01 \pm 0.05$ & $1.90 \pm 0.03$ & $1.83 \pm 0.25$ & $1.58 \pm 0.04$ & $2.04 \pm 0.04$ & $2.02 \pm 0.22$ & $1.91 \pm 0.10$ & $2.06 \pm 0.15$ \\
\hline
\end{tabular}


The average manganese content in oat grains in the years of study was $44.7 \mathrm{mg} \cdot \mathrm{kg}^{-1}$. No significant differences between the element content in 2016 and 2017 could be found ( 45.53 and $45.96 \mathrm{mg} \cdot \mathrm{kg}^{-1}$ ). In 2018, the manganese content (Figure 14) was $42.83 \mathrm{mg} \cdot \mathrm{kg}^{-1}$, which was a reduction relative to the preceding years. A statistically significant increase of manganese content in seed was observed under the influence of Ascophyllum nodosum fertilization (from $44.71 \mathrm{mg} \cdot \mathrm{kg}^{-1}$ to $46.71 \mathrm{mg} \cdot \mathrm{kg}^{-1}$ and $\left.46.46 \mathrm{mg} \cdot \mathrm{kg}^{-1}\right)$.

The mean zinc content from all objects was $26.16 \mathrm{mg} \cdot \mathrm{kg}^{-1}$ for the whole study period. This value differed considerably in each year of the experiment. The highest zinc content was recorded for the seed harvested in $2018\left(29.90 \mathrm{mg} \cdot \mathrm{kg}^{-1}\right)$, whereas the lowest for $2017\left(22.03 \mathrm{mg} \cdot \mathrm{kg}^{-1}\right)$. No statistically significant differences could be found between the objects in terms of the accumulation of this element in the grains.

The three-year average of strontium in oat grain was $1.83 \mathrm{mg} \cdot \mathrm{kg}^{-1}$. The highest level of this element was found for the seed of oat cultivated in 2018. The differences in the content of strontium between objects were not statistically significant.

The iron content (Figure 9), without significant differentiation between factors, was $32.91 \mathrm{mg} \cdot \mathrm{kg}^{-1}$ in $2016,32.81 \mathrm{mg} \cdot \mathrm{kg}^{-1}$ in 2017, and $34.91 \mathrm{mg} \cdot \mathrm{kg}^{-1}$ in 2018, which resulted in the three-year average of $33.48 \mathrm{mg} \cdot \mathrm{kg}^{-1}$; however, a statistically significant difference was found for iron content for the factor algae fertilization. Iron content in the grain was reduced after algae fertilization $\left(35.78 \mathrm{mg} \cdot \mathrm{kg}^{-1}\right.$ for the control group (A0) and $32.52 \mathrm{mg} \cdot \mathrm{kg}^{-1}$ and $32.14 \mathrm{mg} \cdot \mathrm{kg}^{-1}$ for the factor at levels A1 and A2, respectively).

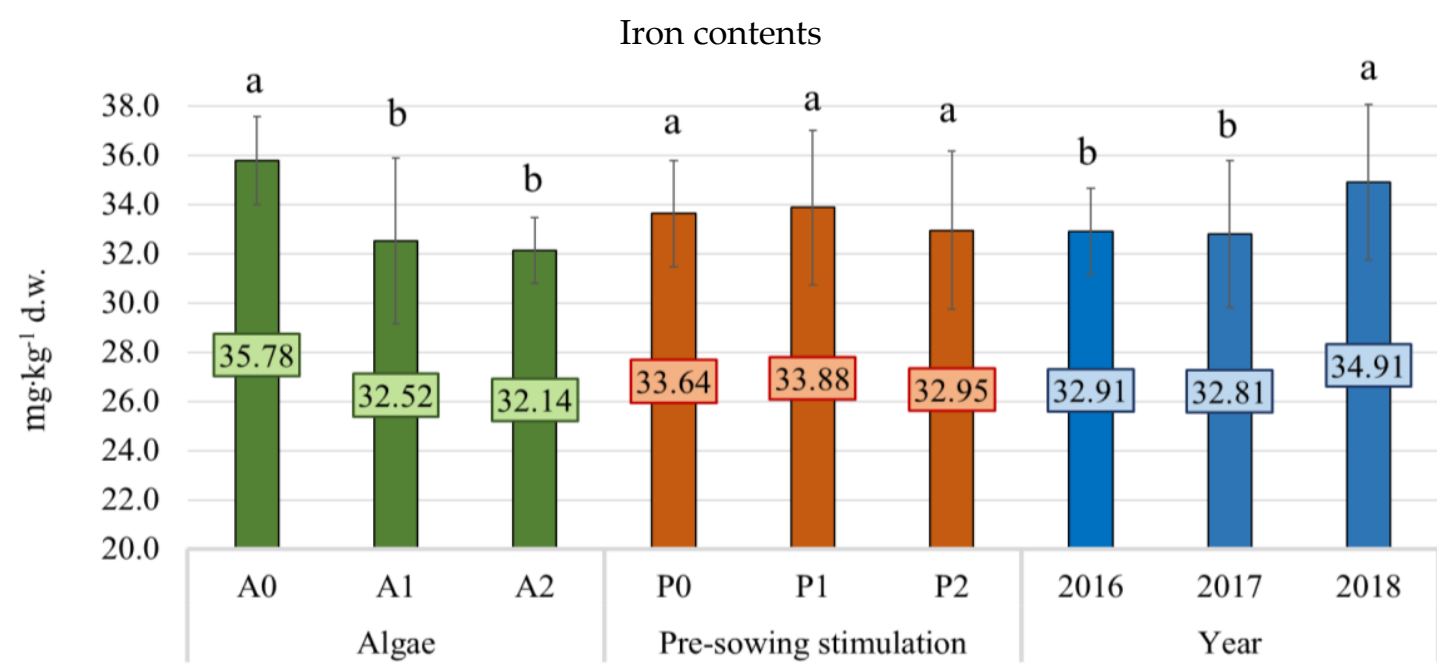

Figure 9. The mean iron content $\left(\mathrm{mg} \cdot \mathrm{kg}^{-1}\right)$ in oat grains in 2016-2018 depending on the experimental factors used. According to Tukey's HSD test, the means marked with the same letter are not significantly different at $\alpha \leq 0.05$.

The average sodium content (Figure 10) in the grain from all three years was $27.0 \mathrm{mg} \cdot \mathrm{kg}^{-1}$. The highest content was found in oat grain harvested in $2016\left(28.24 \mathrm{mg} \cdot \mathrm{kg}^{-1}\right)$. A tendency for the accumulation of higher sodium concentrations in the three-year study cycle was observed for algae fertilization. The three-year average for the algae fertilization factor was $24.1 \mathrm{mg} \cdot \mathrm{kg}^{-1}$ for the A0 level (control), $27.41 \mathrm{~g} \cdot \mathrm{kg}^{-1}$ for the factor at the A1 level, and $29.4 \mathrm{mg} \cdot \mathrm{kg}^{-1}$ for the factor at the A2 level. The differences were statistically confirmed. For the average from the control objects (A0), the content of this element was recorded at $24.08 \mathrm{mg} \cdot \mathrm{kg}^{-1}$, for A1 level-27.41 $\mathrm{mg} \cdot \mathrm{kg}^{-1}$, and A2 level-29.36 $\mathrm{mg} \cdot \mathrm{kg}^{-1}$. 
Sodium contents

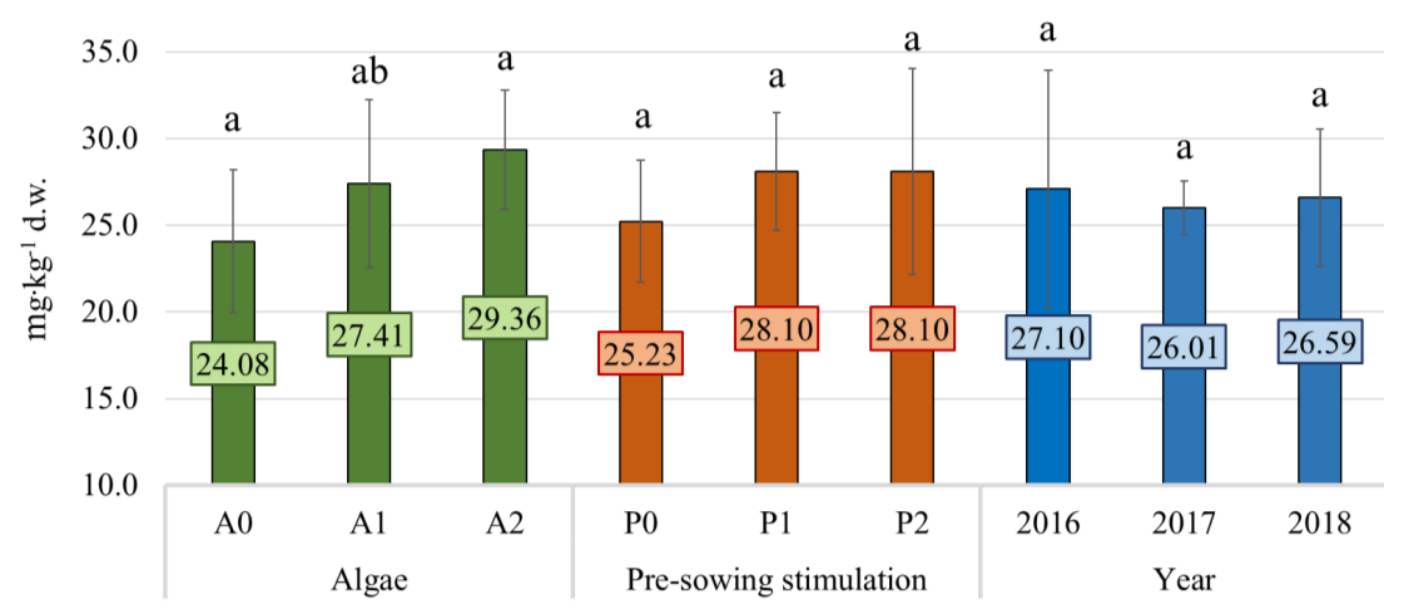

Figure 10. The mean sodium content $\left(\mathrm{mg} \cdot \mathrm{kg}^{-1}\right)$ in oat grains in 2016-2018 depending on the experimental factors used. According to Tukey's HSD test, the means marked with the same letter are not significantly different at $\alpha \leq 0.05$.

The mean molybdenum content (Figure 11) in 2016-2018 in the dry weight of oat grain was $0.76 \mathrm{mg} \cdot \mathrm{kg}^{-1}$. The significant tendency for molybdenum content to increase under the impact of algae fertilization was observed. The mean for the $2016-2018$ period was $0.74 \mathrm{mg} \cdot \mathrm{kg}^{-1}$ for control (factor level A0) and a mean of $0.77 \mathrm{mg} \cdot \mathrm{kg}^{-1}$ for objects fertilized at A1 and A2 levels.

\section{Molybdenum contents}

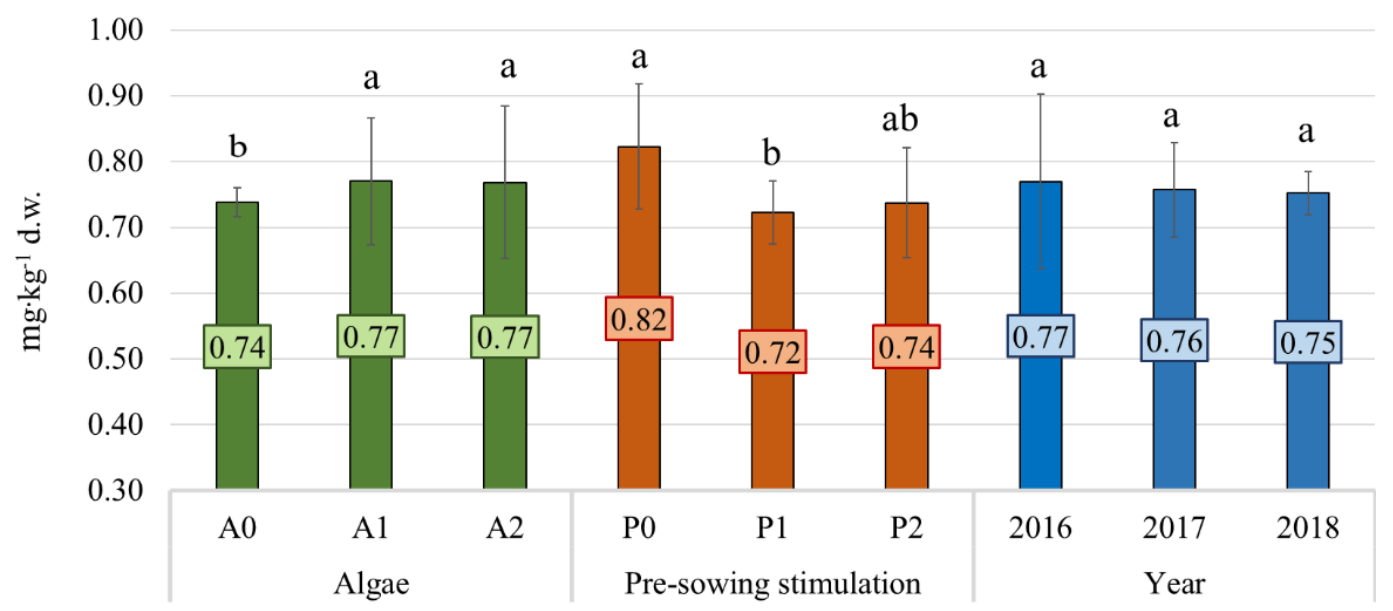

Figure 11. The mean molybdenum content $\left(\mathrm{mg} \cdot \mathrm{kg}^{-1}\right)$ in oat grains in 2016-2018 depending on the experimental factors used. According to Tukey's HSD test, the means marked with the same letter are not significantly different at $\alpha \leq 0.05$.

FT-Raman spectra for 2016, 2017, and 2018 are shown in Figure 12a, Figure 13a, and Figure 14a, respectively. In each spectrum, vibrations corresponding to sugars, proteins, and lipids were noticed. Peaks between $810 \mathrm{~cm}^{-1}$ and $975 \mathrm{~cm}^{-1}$ wavenumbers correspond to stretching vibrations of the C-C group. The peaks at $920-960,1190$, and $1455 \mathrm{~cm}^{-1}$ originate from C-C and C-H vibrations from amylase and other sugars. The vibrations 1260,1382 , and $1338 \mathrm{~cm}^{-1}$ correspond to amide III and the secondary structure of proteins ( $\alpha$-helix). In the FT-Raman spectra of oat grains peaks at 1550 and $1637 \mathrm{~cm}^{-1}$ originate from C-O group building proteins and fats. The last analyzed region $\left(2800-3000 \mathrm{~cm}^{-1}\right)$ corresponds to $\mathrm{C}-\mathrm{H}$ groups that are part of the carbon chains of fatty acid residues. 
Consequently, the positions and the intensities of peaks visible in the FT-Raman spectra differed in each sample in one particular year. The shift of peaks means that the structural changes in the chemical compound are built for functional groups which correspond to these peaks. The local chemical environments were found to differ. The shift can also indicate changes in the chemical composition, whereas the changes in the intensities can also mean differences in the amount of chemical composition which are built of analyzed functional groups.
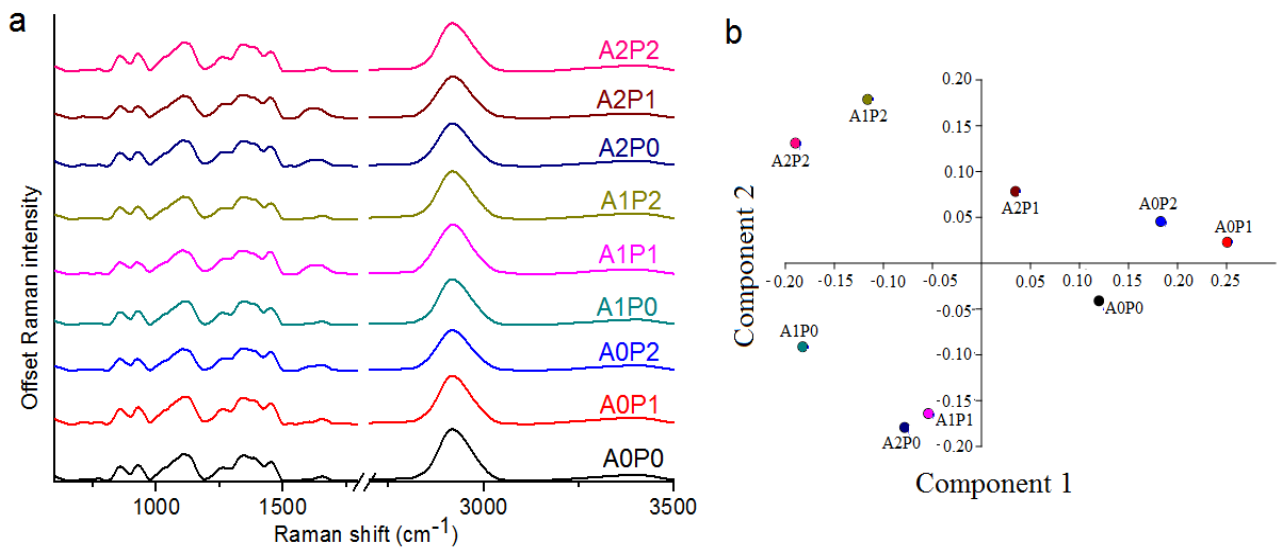

Figure 12. (a) FT-Raman spectra of oat grains (2016); (b) PCA analysis of FT-Raman spectra of oat grains in 800-1800 $\mathrm{cm}^{-1}$ where A0P0—no fertilizer, no magnetostimulation; A0P1—no fertilizer, short magnetostimulation; A0P2—no fertilizer, longer magnetostimulation; A1P0—average dose of algae, no magnetostimulation; A1P1-average dose of algae, short magnetostimulation; A1P2-average dose of algae, longer magnetostimulation; A2P0 - maximum dose of algae, no magnetostimulation; A2P1-maximum dose of algae fertilizer, short magnetostimulation; A2P2-medium dose of algae, longer magnetostimulation.

We observed higher values of Raman scattering intensity characteristic for amylose and amylopectin-building functional groups compared to control (A0) in plant grains that were fertilized by Ascophyllum sp. in doses A1 and A2. Changing the fertilization dose also affected the secondary structure of the protein (changing the nature of the spectrum). Oat grains from plants whose seed was treated longer with the magnetic field (P2) were characterized by higher absorbance values for sugar and protein-building functional groups compared to P0 (control) and P1 (with shorter exposure time). PCA analysis (Figure 12b) showed that in the absence of fertilization (A0P0), magnetostimulation causes chemical changes (A0P1 and A0P2); however, these changes are very similar. Grains fertilized with an average dose of fertilizer (A1P0) and subjected to a six-second magnetostimulation show a similar chemical structure; however, magnetic field simulation for $60 \mathrm{~s}$ has an impact on the chemical composition of the grains. The greatest effect of magnetostimulation was observed at the highest dose of fertilizer. The magnetic field interaction caused changes in the chemical structure of oats when applied for six seconds. We observed a lack of chemical similarity between the grains that have been fertilized with different doses of fertilizer. Furthermore, the amount of fertilizer has a very large impact on the chemical composition of oat grains.

Based on the results of FT-Raman spectroscopy, we determined that the magnetostimulation supported the action of the Ascophyllum nodosum fertilizer, but the algae constituted the main factor that resulted in changes in the composition of the grain. An increase in their dosage resulted in increased amylopectins and amyloses content in the oat grain. In 2017, with increased dosage of the fertilizer, the protein content was reduced, while the starch components content increased. Structural differences were also observed-a change in the algae fertilization dosage influenced the secondary protein structure (change in the spectrum character).

The results of spectroscopic measurements of oat grain for 2017 are presented in Figure 13a. 


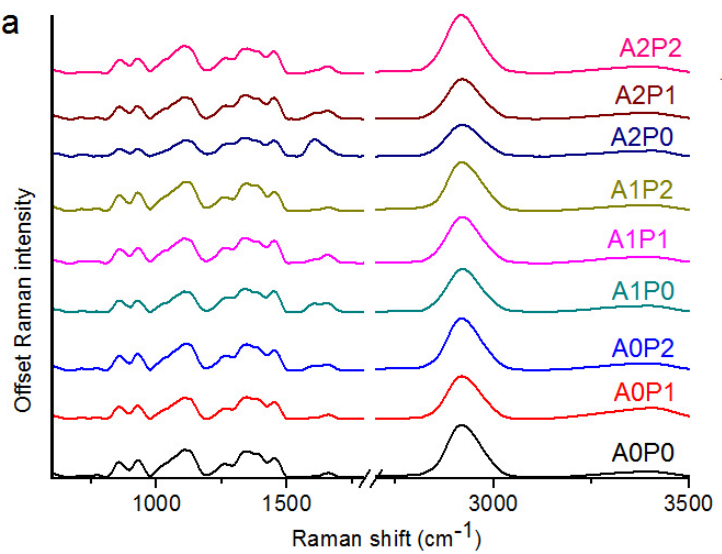

b

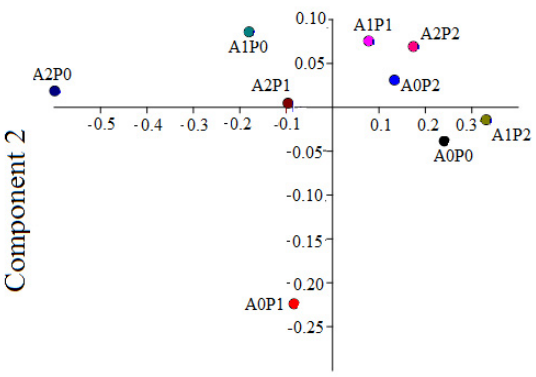

Component 1

Figure 13. (a) FT-Raman spectra of oat grains (2017); (b) PCA analysis of FT-Raman spectra of oat grains in $800-1800 \mathrm{~cm}^{-1}$ where A0P0 - no fertilizer, no magnetostimulation; A0P1—no fertilizer, short magnetostimulation; A0P2 — no fertilizer, longer magnetostimulation; A1P0—average dose of algae, no magnetostimulation; A1P1—average dose of algae, short magnetostimulation; A1P2-average dose of algae, longer magnetostimulation; A2P0-maximum dose of algae, no magnetostimulation; A2P1-maximum dose of algae fertilizer, short magnetostimulation; A2P2-maximum dose of algae, longer magnetostimulation.

Fertilization of oats at doses A1 and A2 led to changes in the chemical composition of the grains. Raman intensity values for functional groups that build amylose and amylopectin increased with the dose of brown algae. In the case of protein functional groups, a decrease in Raman intensity was observed for grains from plots with properties A at level 3 (A2).

To assess whether the visible differences in chemical composition were significant and whether it is possible to distinguish different groups (objects) by Raman spectroscopy, a PCA analysis was performed (Figure 13b).

The PCA analysis showed that in the absence of the introduction of factor A (A0), magnetostimulation affected the chemical changes in oat grain (A0P1 and A0P2). These changes correlated with the length of the magnetic field applied at the pre-sowing stage. Similar differences can be seen for grains with average (A1P0-P2) and the highest dose of fertilizer (A2P0-P2) from seeds subjected to and not subjected to magnetostimulation. PCA analysis indicated that the application of Ascophyllum sp. not assisted by magnetostimulation leads to changes in the composition and chemical structure of the analyzed oat grains.

The results of spectroscopic measurements from 2018 are presented in Figure 14a.

The chemical changes observed between successively examined objects indicate the influence of both factors on the chemical composition of oat grains. This observation is visible in each surveyed year (2016-2018). Plant grains that have been given an algal dose at levels A1 and A2 present higher Raman intensities for amylose and amylopectin-building functional groups compared to control (A0). Plants with the A2-fertilizer dose contain less fatty function groups in comparison to other examined objects (A0 and A1). The grains of oat plants, whose seed was stimulated for longer by the magnetic field (P2), present extended absorbance values for functional groups building sugars and proteins relative to objects with P properties (magnetic field) at P0 (control) and P1 (shorter magnetic field action time). The intensities on the Raman spectra responsible for the vibration of fats for grains treated for $60 \mathrm{~s}$ magnetic contain smaller values than for grains not treated with a magnetic field and treated for six seconds. PCA analysis (Figure 14b) showed that both the lack of fertilizer (A0P0) as well as its highest dose (A2P0), without the magnetic field, act similarly to the chemical composition of sheep grains. For these two groups (no fertilizer and the highest dose of fertilizer) subjected to the action of the magnetic field, the duration of the magnetic field must be the longest for the lack of fertilizer and the shortest for the highest dose of fertilizer for the tendency to influence the chemical composition to 
be maintained. We can conclude from this that the magnetic field supports the fertilizer, but its dose has a major impact on the chemical composition of the grains.
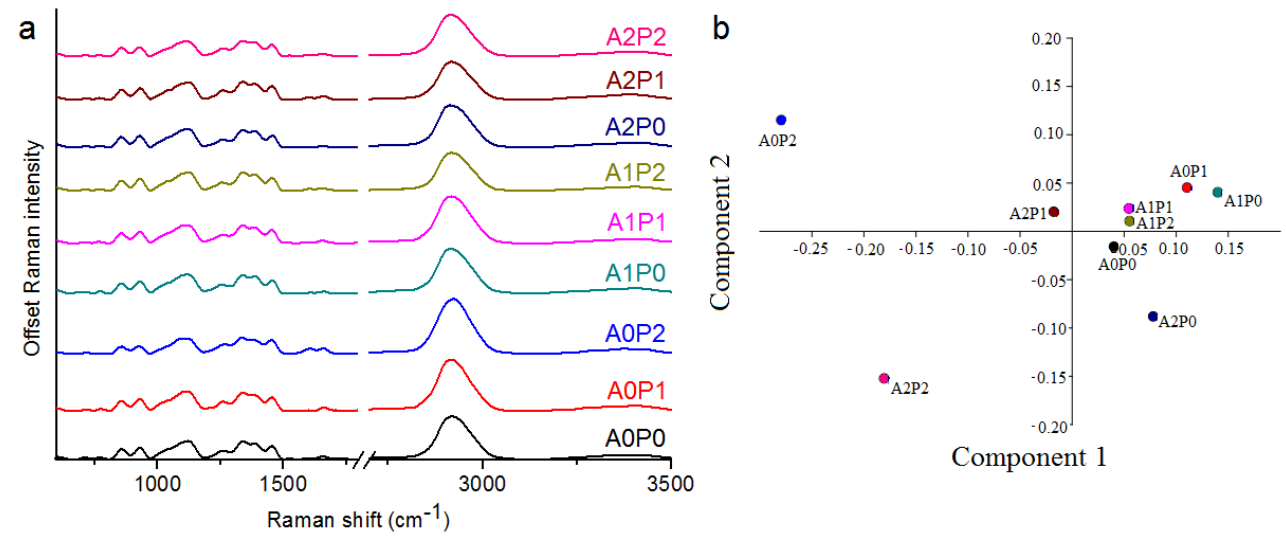

Figure 14. (a) FT-Raman spectra of oat grains (2018); (b) PCA analysis of FT-Raman spectra of oat grains in $800-1800 \mathrm{~cm}^{-1}$ where A0P0 - no fertilizer, no magnetostimulation; A0P1—no fertilizer, short magnetostimulation; A0P2 — no fertilizer, longer magnetostimulation; A1P0 — average dose of algae, no magnetostimulation; A1P1—average dose of algae, short magnetostimulation; A1P2-average dose of algae, longer magnetostimulation; A2P0-maximum dose of algae, no magnetostimulation; A2P1-maximum dose of algae fertilizer, short magnetostimulation; A2P2-maximum dose of algae, longer magnetostimulation.

Based on the results of FT-Raman spectroscopy, it was determined that the magnetostimulation supported the action of the Ascophyllum nodosum fertilizer, but the algae constituted the main factor that caused changes in the composition of the grain. An increase in their dosage resulted in increased amylopectins and amyloses content in the oat grain. In 2017, with an increased dosage of the fertilizer, the protein content was reduced, while the starch components content increased. Structural differences were also observed-changes in the algae fertilization dosage influenced the secondary protein structure (change in the spectrum character).

\section{Discussion}

The three-year average of total protein in oat grain was approximately $117 \mathrm{~g} \cdot \mathrm{kg}^{-1}$. According to literature data [58], this value has a span of 115 to over $140 \mathrm{~g} \cdot \mathrm{kg}^{-1}$. Results at the level of up to $180 \mathrm{~g} \cdot \mathrm{kg}^{-1}$ have been recorded $[58,59]$. Application of the algae at the highest dose (A2) influenced the reduction of the total protein content by $2.22 \%$ relative to control [56]. The lowest protein content was found in grain from the 2017 season (with a mean of $10.38 \%$ protein in dry weight), whereas the highest was found in 2016 (13.13\% d.w.). As stated in the literature [58], the course of weather conditions, primarily the distribution of precipitation in the vegetation period is a factor with a significant modifying impact on the level of protein level in oat. According to another author, although the date and density of sowing have a documented impact on seed yield, the impact of these factors on their protein content has not been proven [57]. This is in line with our results, according to which the year of experiment had greater importance for protein formation in the yield. The grain of oat cultivated may significantly differ in their chemical composition when in different conditions and areas-particularly protein content. Results of the qualitative spectroscopic testing point to a certain differentiation of this trait between the tested factor combinations [58].

In the case of raw fat content in the grain, the average from all years of the experiment was 3.89\% d.w. A significant interaction between the factors was found for the formation of lipid content in 2016; however, algae fertilization and pre-sowing stimulation with the magnetic field separately did not have a significant impact on lipid content in oat grain. This result is not surprising, as, according to the literature [58], lipid content in oat grain is a more stable trait and is subject to less pronounced 
fluctuations than protein content due to environmental conditions. The highest content of raw fat in dry grain weight, at $4.17 \%$, was recorded in 2017 , whereas its lowest content at $3.53 \%$ was recorded in 2016. It can be stated that the experiment year significantly modified the raw lipid content in oat grain. According to another study, with increased protein content in oat grain, a simultaneous decrease in fat content can be observed [60]. This relationship was confirmed in the present study. The highest protein content $(13.13 \%$ d.w.) and the lowest raw lipid content (3.53\%) in grain were determined in 2016 out of the three years of the experiment; however, these contents were reversed in 2017 -at $10.38 \%$ d.w. for protein and $4.17 \%$ for raw fat. The reduction of protein content and increased fat content under the influence of foliar fertilization with a product containing A. nodosum was also observed [56].

The raw fiber content in oat grain dry weight was on average $11.83 \%$. Its highest content $(12.14 \%)$ was recorded in 2018 and lowest in 2016 (11.28\%). This content was statistically significantly differentiated between the years of study. These results comply with the literature data, where the content of raw fiber in the raw material of oat grain ranged between $11 \%$ and $16 \%$ [58].

The mean ash content from 2016 to 2018 was $2.6 \%$, and this value is in agreement with the literature data [45]. The significant impact of algae fertilization on ash content in oat grain was determined. Fertilization with algae at the higher A2 dose resulted in reduced ash content in oat grain (by 1.19\%). Ash content in oat grain was determined by the years of study. The highest amount of ash was determined in the grain harvested in $2016(2.82 \%)$ and the lowest in $2017(2.23 \%)$. The content of nitrogen-free extract (NFE) in oat grain in 2016-2018 was on average $62.4 \%$, attaining its highest value in the 2017 vegetation season $(63.71 \%)$. No statistically significant differences could be found for the obtained results between the oat objects, as well as between the years of the experiment. In the conducted experiment, the oat organic composition was largely determined by the years of study, and thus by their weather conditions. Interactions between individual factors may be important for the development of the chemical composition. According to another author, increased total protein content in oat grain may occur with late sowing, with a simultaneous considerable reduction in seed yield, and it appears that this may explain the yield and protein content in 2016 [57].

Raman spectroscopy was used to investigate the organic composition of oat grain. To summarize the three-year experiment, in objects A0P2 (no algae fertilization, shorter magnetic field exposure time), similar chemical composition was found to the grain of A1P0 plants, whose sowing material was not treated with the magnetic field, but were fertilized with a medium fertilizer dosage. Similar results were obtained for fertilizing with a medium dose of the fertilizer and pre-sowing treatment with the magnetic field for $60 \mathrm{~s}$ (A1P2) in comparison to the grain of plants exposed to the highest fertilizer dose, without pre-sowing magnetostimulation (A2P0). It can be concluded from this that magnetostimulation supported the fertilizer, but the main factor causing changes in the composition of oat is fertilizer, which was also found by measuring the quantitative characteristics of the grain. Algae fertilization also resulted in an increased content of amyloses and amylopectins, i.e., starch components in the grain. Under the influence of the field, Raman scattering intensities increased for sugars and proteins, and decreased for fatty acids. Change of the algae fertilization dosage further influenced the secondary protein structure (change in the spectrum character). The importance of sulfur (which is also a component of $A$. nodosum) was emphasized not only for protein synthesis, but also for maintaining the structure of secondary and tertiary proteins and their spatial conformation [61].

The content of macronutrients in oat grain, such as potassium, phosphorus, calcium, magnesium, and sulfur, in 2016 is provided in $\mathrm{g} \cdot \mathrm{kg}^{-1}$. The mean potassium content in oat grain throughout the experiment was $4.14 \mathrm{~g} \cdot \mathrm{kg}^{-1}$. This result was slightly lower in comparison to the literature data [45] regarding non-hulled forms and slightly higher than the average value provided for Avena sativa [52]. The highest potassium concentration in the grain was determined in $2017\left(4.34 \mathrm{~g} \cdot \mathrm{kg}^{-1}\right)$, which was characterized by a course of weather conditions more favorable for oat vegetation in contrast to seasons 2016 and 2018 for which this value was 4.02 and $4.05 \mathrm{~g} \cdot \mathrm{kg}^{-1}$, respectively. The mean content of phosphorus from the three years of study of the analyzed objects was $3.79 \mathrm{~g} \cdot \mathrm{kg}^{-1}$, which complies with the literature data that assessed this value for non-hulled forms at the level between 3.3 and 
$4.0 \mathrm{~g} \cdot \mathrm{kg}^{-1}$ [45]. The highest content of this element was recorded in $2018\left(4.06 \mathrm{~g} \cdot \mathrm{kg}^{-1}\right)$; for seasons 2016 and 2017 it was 3.73 and $3.57 \mathrm{~g} \cdot \mathrm{kg}^{-1}$, respectively. The average three-year content of calcium in all tested objects was $1.11 \mathrm{~g} \cdot \mathrm{kg}^{-1}$, which also remains within the range known from the literature-between 1.11 and $1.6 \mathrm{~g} \cdot \mathrm{kg}^{-1} \mathrm{~d} . \mathrm{w}$. [45]. A reduction in the calcium content in the grain was observed along with increasing the applied dosage of algae, which was, respectively, $1.16 \mathrm{~g} \cdot \mathrm{kg}^{-1}$ at the A0 level (control), $1.12 \mathrm{~g} \cdot \mathrm{kg}^{-1}$ at the A1 level, and $1.05 \mathrm{~g} \cdot \mathrm{kg}^{-1}$ at the A2 level in the three-year average. This can be explained by the fact that calcium cation is taken up at a considerably slower rate than other ions, and that the calcium concentration can be influenced by simultaneous potassium fertilization, for instance [62]. In one of the experiments, the researcher also determined decreased calcium concentration in spring wheat grain under the influence of auxin application (also present in Ascophyllum nodosum). Citing the author, the growth regulators modified calcium content in the plants to a greater extent than the fertilization level [62]. Application of phytohormones restricted calcium and magnesium accumulation in both the grain as well as vegetative organs of wheat. In the present study, the average magnesium content in oat grain from the three years of the experiment was $1.48 \mathrm{~g} \cdot \mathrm{kg}^{-1}\left(1.30 \mathrm{~g} \cdot \mathrm{kg}^{-1}\right.$ for 2016 and 2018 and $1.83 \mathrm{~g} \cdot \mathrm{kg}^{-1}$ for the 2017 season), which is in further agreement with the literature data [45]. The magnesium content in the examined oat grain samples was differentiated by the year factor and not by algae application and pre-sowing magnetic field stimulation. This result did not come as a surprise as oat grain chemical composition is primarily influenced by genetic and environmental factors, e.g., the type and humidity of the soil, fertilization level, or insolation [58]. The application of the experimental factors did not lead to significant changes in sulfur content, which remained at an average level of $1.46 \mathrm{~g} \cdot \mathrm{kg}^{-1}$ for all years of the experiment. A tendency was observed in 2017 for lower sulfur content when the grain was observed in contrast to 2016 and 2018. Similar results in terms of macronutrient content in oat grain were provided [63]. In the experiment carried out on lettuce, an $A$. nodosum based preparation resulted in increased yield relative to control without changing the content of phosphorus and potassium, among other elements [64].

The micronutrients measured in oat grain in 2016-2018 included the mean content of copper, iron, manganese, sodium, molybdenum, zinc, and strontium, and the results are provided in $\mathrm{mg} \cdot \mathrm{kg}^{-1}$. The mean copper content in oat grain from all objects was $3.15 \mathrm{mg} \cdot \mathrm{kg}^{-1}$, which is in line with the value known from literature data. Citing the literature, the copper content in the grain of oat cultivated in controlled pot conditions was determined at $3.08-4.11 \mathrm{mg} \cdot \mathrm{kg}^{-1}$, depending on the fertilization applied [64]. The statistically significant influence of magnetic field pretreatment on the content of copper in the grain was observed in 2017, where the mean level for the P0 level (control) was $3.12 \mathrm{mg} \cdot \mathrm{kg}^{-1}, 3.29 \mathrm{mg} \cdot \mathrm{kg}^{-1}$ for the P1 level, and $3.48 \mathrm{mg} \cdot \mathrm{kg}^{-1}$ for the P2 level. The effect was opposite to the study conducted on sugar beet seed. In the cited study, following the application of pre-sowing low-frequency magnetic field stimulation, also with $50 \mathrm{mT}$ induction, a limited transfer and uptake of nutrients by beet plants was observed [65]. When analyzing this type of result, it is important to remember that the mechanism of the magnetic field effect on plants has not yet been precisely and unambiguously explained [32] and the hypotheses referring to the effect of these fields on plants do not explain all of the phenomena [20,32]. The effect of the magnetic field further varies between plant species. Iron content was on average $33.48 \mathrm{mg} \cdot \mathrm{kg}^{-1}$ in all objects. That is slightly lower than found under conditions of a pot experiment [64]. Statistically significant differences were found for iron content, and when following algae application, it was reduced from $35.78 \mathrm{mg} \cdot \mathrm{kg}^{-1}$ for the control to about $32 \mathrm{mg} \cdot \mathrm{kg}^{-1}$ at the A1 and A2 levels. When analyzing this result, the effects associated with hormone levels described in the literature should be taken into account [5]. The secondary metabolites of Ascophyllum nodosum have not been yet discovered or studied. Iron content may be subject to considerable variation in oat grain, up to three-fold, which is associated with genetic factors [50]. The manganese content in oat grain in the experiment period was on average $44.7 \mathrm{mg} \cdot \mathrm{kg}^{-1}$. This value was almost identical to the content of this element obtained by other authors $-44.2 \mathrm{mg} \cdot \mathrm{kg}^{-1}[52,65]$. The literature states that manganese content in the grain of properly cultivated oat may range between 35 and $99 \mathrm{mg} \cdot \mathrm{kg}^{-1}$ [48]. In the present study, in the 2017 season, a statistically significant increase of 
manganese content in grain was observed under the impact of algae application (from $44.71 \mathrm{mg} \cdot \mathrm{kg}^{-1}$ to approximately $46.5 \mathrm{mg} \cdot \mathrm{kg}^{-1}$ ), indicating that algae fertilizer constitutes a good source of this micronutrient. The mean sodium content in grain was $26.95 \mathrm{mg} \cdot \mathrm{kg}^{-1}$ over the study period. Its highest content was determined in oat grain harvested in $2016\left(28.24 \mathrm{~g} \cdot \mathrm{kg}^{-1}\right)$. A tendency for higher sodium accumulation in the three-year study cycle was observed for algae fertilization (statistically significant for the 2018 season), where these values were as follows: the mean content of this element from control objects (A0) was $24.08 \mathrm{mg} \cdot \mathrm{kg}^{-1}, 27.41 \mathrm{mg} \cdot \mathrm{kg}^{-1}$ at the A1 level, and $29.36 \mathrm{mg} \cdot \mathrm{kg}^{-1}$ at the A2 level, which stems from the high content of this element in the Ascophyllum algae biomass, which naturally occurs in marine waters. The mean molybdenum content in 2016-2018 for all objects was $0.76 \mathrm{mg} \cdot \mathrm{kg}^{-1}$. A tendency for increasing molybdenum content was observed under the influence of algae application in each year of the study, and these differences were statistically confirmed for 2018, where the molybdenum content in control (A0) was on average $0.72 \mathrm{mg} \cdot \mathrm{kg}^{-1}, 0.75 \mathrm{mg} \cdot \mathrm{kg}^{-1}$ in groups (objects) with the factor $\mathrm{A}$ at the level of $\mathrm{A} 1$, and $0.78 \mathrm{mg} \cdot \mathrm{kg}^{-1}$ at the $\mathrm{A} 2$ level. This result validates the application of algae as a source of molybdenum in plant fertilization. The mean zinc content in the oat grain in the study period was $26.16 \mathrm{mg} \cdot \mathrm{kg}^{-1}$, slightly lower than that determined by other authors [65]. This value differed considerably in each year of the experiment. The highest zinc content was found in grain from the 2018 season $\left(29.90 \mathrm{mg} \cdot \mathrm{kg}^{-1}\right)$, the lowest in grain from the 2017 season $\left(22.03 \mathrm{mg} \cdot \mathrm{kg}^{-1}\right)$; however, no modification of this trait could be found after the application of the experimental factors. This is confirmed in the study of other researchers, who explain that it was the weather conditions after the vegetation period that had a significant modifying impact on oat grain composition $[57,58]$. Interestingly, the other study determined that the content of zinc may differ up to seven-fold between the grain of different oat genotypes, with a range of 10 to $70 \mathrm{mg} \cdot \mathrm{kg}^{-1}$ [48].

The three-year average of strontium content in oat grain was $1.83 \mathrm{mg} \cdot \mathrm{kg}^{-1}$ and the differences in the content of strontium between objects were not statistically significant. In the analysis of the mineral composition, changes of significance for its modification by experimental factors were determined for calcium, copper, iron, manganese, sodium, and molybdenum. No statistically significant influence of the tested factors on potassium, magnesium, sulfur, phosphorus, zinc, or strontium could be found.

The present study did not produce such favorable outcomes of the low-frequency magnetic field exposure to the seed on germination, growth, and yield increase as those available in many other studies that described favorable effects of magnetic field exposure-primarily in the acceleration of germination and seedling growth $[20,66]$; however, it should be noted that the considerable majority of described experiments were conducted under pot or greenhouse conditions, where weather, environmental, or habitat conditions had no impact. Certain differences can be more easily noted in stable pot conditions, which are otherwise difficult or impossible to determine under field cultivation conditions (e.g., higher germination rate). The experiment from 1977 did not demonstrate any reaction of oat to pre-sowing stimulation [67]. The lack of the magnetic field's effect on germination and seedling growth was determined in both Avena sativa as well as in Avena fatua. Polish researchers also did not find increased cereal yield under the influence of pre-sowing seed stimulation based on a study on spring wheat [68]. Increased content of such elements as nitrogen, potassium, calcium, magnesium, iron, manganese, sodium, and zinc under the influence of the magnetic field was determined [69]; however, the content of phosphorus and sulfur decreased. It should be noted that the exposure to the magnetic field was constant in their case. Numerous researchers have pointed to the fact that the chemical composition of plants may be influenced by their surrounding environment, local geoclimate, seasonal changes, factors such as light, temperature, soil humidity, and fertility, as well as cultivation technology, which was also confirmed by the presented study $[70,71]$.

\section{Conclusions}

I. Application of algae at the highest dose A2 resulted in decreased content of total protein in oat grain by $2.22 \%$ and reduced ash content by $1.19 \%$ relative to control.

II. Oat fertilization with algae influenced the content of macro- and micronutrients in the grain. 
a. The reduction of calcium and iron content was determined in oat grain under the influence of the applied algae dose. For the A2 fertilization level, these values were $9.5 \%$ and $10.2 \%$, respectively.

b. Increasing the dosage of algae fertilization resulted in increased content of sodium and molybdenum in oat grain. For the A2 dosage, these values were $21.9 \%$ and $4.1 \%$, respectively.

III. Fertilization of Ascophyllum nodosum resulted in increased content of starch components, i.e., amyloses and amylopectins in oat grain.

Author Contributions: Important contributions to the design and preparation of the manuscript: B.D. Contributions to sample and analysis experiments: B.D., J.D., and G.Z. Analysis of the experimental data: B.D. Critical revision for important intellectual content: B.D., J.D., and C.P. Supervision C.P. All authors helped prepare the paper and approved the final version. All authors have read and agreed to the published version of the manuscript.

Funding: This publication is funded under the Minister of Science and Higher Education program "Regionalna Inicjatywa Doskonałości" (Regional Initiative of Excellence) for the years 2019-2022, project no. 026/RID/2018/19, funding amount PLN 9542500.00 PLN.

Conflicts of Interest: The authors declare no conflict of interest.

\section{References}

1. Algabase. 2018. Available online: https://www.algaebase.org/search/species/detail/?species_id=5 (accessed on 20 December 2018).

2. Sabir, A.; Yazar, K.; Sabir, F.; Kara, Z.; Yazici, M.A.; Goksu, N. Vine growth, yield, berry quality attributes and leaf nutrient content of grapevines as influenced by seaweed extract (Ascophyllum nodosum) and nanosize fertilizer pulverizations. Sci. Hortic. 2014, 175, 1-8. [CrossRef]

3. Khan, W.; Rayirath, U.P.; Subramanian, S.; Jithesh, M.N.; Rayorath, P.; Hodges, D.M.; Crithley, A.T.; Craigie, J.S.; Norrie, J.; Prithviraj, B. Seaweed extracts as biostimulants of plant growth and development. J. Plant Growth Regul. 2009, 28, 386-399. [CrossRef]

4. Nair, P.; Kandasamy, S.; Zhang, J.; Ji, X.; Kirby Ch Benkel, B.; Hodges, M.D.; Crithley, A.T.; Hitz, D.; Prithviraj, B. Transcriptional and metabolomic analysis of Ascophyllum nodosum mediated freezing tolerance in Arabidopsis thaliana. BMC Genom. 2012, 13, 643. [CrossRef]

5. Wally, O.S.D.; Critchley, A.T.; Hiltz, D.; Han, X.; Zaharia, L.I.; Abrams, S.R.; Prithiviraj, B. Regulation of pytohormone bosynthesis and acumulation in Arabidopsis fllowing teatment with cmmercial ctract from the Marine Macroalga Ascophyllum nodosum. J. Plant Growth Regul. 2013, 32, 324-339. [CrossRef]

6. Rathore, S.S.; Chaudhary, D.R.; Boricha, G.N.; Ghosh, A.; Bhatt, B.P.; Zodape, S.T.; Ptolia, J.S. Effect of seaweed extract on the growth, yield and nutrient uptake of soybean (Glycine max) under rainfed conditions. S. Afr. J. Bot. 2009, 75, 351-355. [CrossRef]

7. Mansori, M.; Chernane, H.; Latique, S.; Benaliat, A.; Hsissou, D.; El Kaoua, M. Seaweed extract effect on water deficit and antioxidative mechanisms in bean plants (Phaseolus vulgaris L.). J. Appl. Phycol. 2015, 27, 1689-1698. [CrossRef]

8. Latique, S.; Chernane, H.; Mansori, M.; El Kaoua, M. Seaweed liquid fertilizer effect on physiolgical and biochemical parameters of bean plant (Phaseolus vulgaris variety paulista) under hydroponic system. ESJ 2013, 9, 174-191.

9. Fan, D.; Hodges, D.M.; Zhang, J.; Kirby, H.W.; Ji, X.; Locke, S.J.; Critchley, A.T.; Prithiviraj, B. Commercial extract of the brown seaweed Ascophyllum nodosum enhances phenolic antioxidant content of spinach (Spinacia oleracea L.) which protects Caenorhabditis elegans against oxidative and thermal stress. Food Chem. 2011, 124, 195-202. [CrossRef]

10. Spann, T.M.; Little, H.A. Applications of a Commercial Extract of the Brown Seaweed Ascophyllum nodosum Increases Drought Tolerance in Container-grown 'Hamlin' Sweet Orange Nursery Trees. Hort. Sci. 2011, 46, 577-582. [CrossRef] 
11. Khan, W.; Zhai, R.; Souleimanov, A.; Crithley, A.T.; Smith, D.L.; Prithviraj, B. Commercial extract of Ascophyllum nodosum improves root clonization of afalfa by its bacterial symbiont Sinorhizobium meliloti. Commun. Soil Sci. Plan Anal. 2012, 43, 2425-2436. [CrossRef]

12. Alam, M.Z.; Braun, G.; Norrie, J.; Hodges, D.M. Effect of Ascophyllum extract application on plant growth, fruit yield and soil microbial communities of strawberry. Can. J. Plant. Sci. 2013, 93, 23-36. [CrossRef]

13. Alam, M.Z.; Braun, G.; Norrie, J.; Hodges, M. Ascophyllum extract application can promote plant growth and root yield in carrot associated with increased root-zone soil microbial activity. Can. J. Plant Sci. 2014, 94, 337-348. [CrossRef]

14. Zhao, J. Effects of Ascophyllum nodosum Extract on Giant Reed (Arondo donax L.). Master's Thesis, Saint Mary's University, Halifax, NS, Canada, August 2016.

15. Wu, Y.; Jenkins, T.; Blunden, G.; von Mende, N.; Hankins, S.D. Suppression of fecundity of the root-knot nematode, Meloidogyne javanica, in monoxenic cultures of Arabidopsis thaliana treated with an alkaline extract of Ascophyllum nodosum. J. Appl. Phycol. 1998, 10, 91. [CrossRef]

16. Jayraman, J.; Norrie, J.; Punja, Z.K. Commercial extract from the brown seaweed Ascophyllum nodosum reduces fungal diseases in greenhouse cucumber. J. Appl. Phycol. 2011, 23, 353-361. [CrossRef]

17. Dobromilska, R.; Mikiciuk, M.; Gubarewicz, K. Evaluation of cherry tomato yielding and fruit mineral composition after using of Bio-algeen S-90 preparation. J. Elem. 2008, 13, 491-499.

18. Dudaš, S.; Šola, I.; Sladonja, B.; Erhatić, R.; Ban, D.; Poljuha, D. The effect of biostimulant and fertilizer on "low input" lettuce production. Acta Bot. Croat. 2016, 75, 253-259. [CrossRef]

19. Belyavskaya, N.A. Biological effects due to weak magnetic field on plants. Adv. Space Res. 2004, 34, $1566-1574$. [CrossRef]

20. Puchalski, C.; Zaguła, G. Effects of Permanent and Slowly Varying Magnetic Fields in Plants, Animals and Humans; Wydawnictwo Uniwersytetu Rzeszowskiego: Rzeszów, Poland, 2015; p. 72.

21. Kobayashi, M.; Soda, N.; Miyo, T.; Ueda, Y. Effects of combined DC and AC magnetic fields on germination of hornwort seeds. Bioelectromagnetics 2004, 25, 552-559. [CrossRef]

22. Maffei, M.E. Magnetic field effects on plant growth, development, and evolution. Front. Plant Sci. 2014, 5, 445. [CrossRef]

23. Qamili, E.; De Santis, A.; Isac, A.; Mandea, M.; Duka, B.; Simonyan, A. Geomagnetic jerks as chaotic fluctuations of the Earth's magnetic field. Geochem. Geophys. Geosysyst. 2013, 14, 839-850. [CrossRef]

24. Occhipinti, A.; De Santis, A.; Maffei, M.E. Magnetoreception: An unavoidable step for plant evolution? Trends Plant Sci. 2014, 19, 1-4. [CrossRef] [PubMed]

25. Pittman, U.J. Magnetism and Plant Growth: I. Effect of germination and early growth of cereal seeds. Can. J. Plant Sci. 1963, 43, 513-518. [CrossRef]

26. Lebedev, S.I.; Baranskiy, P.I.; Litvinenko, L.G.; Shiyan, L.T. Barley growth in superweak magnetic field. Electron. Treat. Mater. 1977, 3, 71-73.

27. Rakosy-Tican, L.; Aurori, C.M.; Morariu, V.V. Influence of near null magnetic field on in vitro growth of potato and wild Solanum species. Bioelectromagnetics 2005, 26, 548-557. [CrossRef] [PubMed]

28. Xu, C.X.; Yin, X.; Lv, Y.; Wu, C.Z.; Zhang, Y.X.; Song, T. A near-null magnetic field affects cryptochrome-related hypocotyl growth and flowering in Arabidopsis. Adv. Space Res. 2012, 49, 834-840. [CrossRef]

29. Xu, C.X.; Wei, S.F.; Lu, Y.; Zhang, Y.X.; Chen, C.F.; Song, T. Removal of the local geomagnetic field affects reproductive growth in Arabidopsis. Bioelectromagnetics 2013, 34, 437-442. [CrossRef]

30. Mahajan, T.S.; Pandey, O.P. Magnetic-time model at off-season germination. Int. Agrophys. 2014, $28,57-62$. [CrossRef]

31. Vashisth, A.; Nagarajan, S. Exposure of seeds to static magnetic field enhances germination and early growth characteristics in chickpea (Cicer arietinum L.). Bioelectromagnetics 2008, 29, 571-578. [CrossRef]

32. Payez, A.; Ghanati, F.; Behmanesh, M.; Abdolmaleki, P.; Hajnorouzi, A.; Rajabbeigi, E. Increase of seed germination, growth and membrane integrity of wheat seedlings by exposure to static and a $10-\mathrm{KHz}$ electromagnetic field. Electromagn. Biol. Med. 2013, 32, 417-429. [CrossRef]

33. Bilalis, D.J.; Katsenios, N.; Efthimiadou, A.; Karkanis, A. Pulsed electromagnetic field: An organic compatible method to promote plant growth and yield in two corn types. Electromagn. Biol. Med. 2012, 31, 333-343. [CrossRef] 
34. Araújo, S.; Paparella, S.; Dondi, D.; Bentivoglio, A.; Carbonera, D.; Balestrazzi, A. Physical methods for seed invigoration: Advantages and challenges in ceed technology. Front. Plant Sci. 2016, 7, 646. [CrossRef] [PubMed]

35. Naz, A.; Jamil, Y.; ul Haq, Z.; Iqbal, M.; Ahmad, M.R.; Ashraf, M.I.; Ahmad, R. Enhancement in the germination, growth and yield of Okra (Abelmoschus esculentus) using pre-sowing magnetic treatment of seeds. IJBB 2012, 49, 211-214.

36. Florez, M.; Carbonell, M.V.; Martinez, E. Early sprouting and first stages of growth of rice seeds exposed to a magnetic field. Electromagn. Biol. Med. 2004, 23, 157-166. [CrossRef]

37. Betti, L.; Trebbi, G.; Fregola, F.; Zurla, M.; Mesirca, P.; Brizzi, M.; Borghini, F. Weak static and extremely low frequency magnetic fields affect in vitro pollen germination. Sci. World J. 2011, 11, 875-890. [CrossRef] [PubMed]

38. Yaycili, O.; Alikamanoglu, S. The effect of magnetic field on Paulownia tissue cultures. Plant Cell Tiss. Organ Cult. 2005, 83, 109-114. [CrossRef]

39. Pittman, U.J. Effect of magnetic seed treatment on yields of barley, wheat, and oats in southern Alberta. Can. J. Plant Sci. 1977, 57, 37-45. [CrossRef]

40. Almaghrabi, O.A.; Elbeshehy, E.F. Effect of weak electro magnetic field on grain germination and seedling growth of different wheat (Triticum aestivum L.) cultivars. Life Sci. J. 2012, 9, 1615-1622.

41. Afzal, I.; Abbasi, K.Y.; Iqbal, A.; Younis, A.; Bakhtavar, M.A.; Ur Rehman, H. Enhancement of zinnia seed germination and seedling emergence through magnetic seed stimulation. Acta Sci. Pol. Hortorum Cultus 2016, 15, 173-184.

42. Iqbal, M.; Ul Hag, Z.; Malik, A.; Ayoub, M.; Jamil, Y.; Nisar, J. Pre-sowing seed magnetic field stimulation: A good option to enhance bitter gourd germination, seedling growth and yield characteristics. Biocatal. Agric. Biotechnol. 2016, 5, 30-37. [CrossRef]

43. Hussain, M.S.; Dastgeer, G.; Afzal, A.M.; Hussain, S.; Kanwar, R.R. Eco-friendly magnetic field treatment to enhance wheat yield and seed germination growth. Environ. Nanotechnol. Monit. Manag. 2020, 14, 100299. [CrossRef]

44. Nyakane, N.E.; Sedibe, M.M.; Markus, E.D. The Effects of Magnetic Fields on Plants Growth: A Comprehensive Review. IJFE 2019, 5, 79-87. [CrossRef]

45. Zarzecka, K.; Gugała, M.; Mystkowska, I.; Baranowska, A.; Sikorska, A.; Zarzecka, M. Nutritional and health-promoting properties of oat grain and oat products. Kosmos 2018, 67, 409-414. (In Polish) [CrossRef]

46. Central Center for Crop Research in the Słupia Wielka. List of Agricultural Plant Species Entered in the Register in Poland. Słupia Wielka. 2018; 50. (In Polish)

47. Musa Özcan, M.M.; Ozkan, G.; Topal, A. Characteristics of grains and oils of four different oats (Avena sativa L.) cultivars growing in Turkey. Nutrition 2006, 57, 345-352. [CrossRef]

48. Bityutskii, N.P.; Loskutov, I.; Yakkonen, K.; Konarev, A.; Shelenga, T.; Khoreva, V.; Blinova, E.; Ryumin, A. Screening of Avena sativa cultivars for iron, zinc, manganese, protein and oil content and fatty acid composition in whole grains. Cereal Res. Commun. 2020, 48, 87-94. [CrossRef]

49. Comini, I.; Moreno, M.L.; Sousa, C. Role of oats in celiac disease. World J. Gastroenterol. 2015, 21, 11825-11831. [CrossRef] [PubMed]

50. Jnawali, P.; Kumar, V.; Tanwar, P. Celiac disease: Overview and considerations for development of gluten-free foods. Food Sci. Hum. Wellness 2016, 5, 169-176. [CrossRef]

51. Biel, W.; Bobko, K.; Maciorowski, R. Chemical composition and nutritive value of husked and naked oat grains. J. Cereal Sci. 2009, 49, 413-418. [CrossRef]

52. Youssef, M.K.E.; Nassar, A.G.; EL-Fishawy, F.A.; Mostafa, M.A. Assessment of proximate chemical composition and nutritional status of wheat biscuits fortified with oat powder. Assiut J. Agric. Sci. 2016, 47, 83-94.

53. Kordulasińska, I.; Bulińska-Radomska, Z. Estimation of morphological, agronomic traits and chemical composition of oat accessions in the national centre for plant genetic resources in Radzików. Pol. J. Agron. 2014, 16, 3-12.

54. Karaś, M.; Jakubczyk, A.; Paczos-Grzęda, E. Właściwości przeciwutleniające hydrolizatów białek z ziarna uprawnych i dzikich gatunków owsa (Avena sativa L.) (Antioxidant properties of protein hydrolysates from crops oats species and wild oats species Avena sativa L.). Żywności. Nauka Technol. Jakość 2013, 6, 106-117. 
55. Tobiasz-Salach, R.; Bobrecka-Jamro, D. Influence of multicomponent foliar of fertilizer on the chemical crop and yield composition of oats. Acta Agrophys. 2003, 85, 89-98.

56. Tobiasz-Salach, R.; Bobrecka-Jamro, D.; Pyrek-Bajcar, E.; Buczek, J. Response of hulled and naked oat to foliar fertilization. Acta Sci. Pol. Agric. 2016, 15, 77-88.

57. Noworolnik, K. The effect of sowing date and harvest date on yields and protein content in grain of oats. Pol. J. Agron. 2011, 6, 34-37.

58. Brzóska, F.; Szymczyk, B.; Szolkowska, A.; Śliwiński, B.; Pietras, M. Amino acid composition, fatty acid profile and nutritional valuegrain of oat varieties and families. Rocz. Nauk. Zootech. 2017, 44, 247-264. (In Polish)

59. Piątkowska, E.; Kopeć, A.; Kidacka, A.; Leszczyńska, T.; Pisulewska, E. The content of nutrients and antioxidant properties of different grain fractions of selected varieties and families of oats. Żywność Nauka Technol. Jakość 2013, 6, 91-105. (In Polish)

60. Sterna, V.; Zute, S.; Jansone, I.; Brunava, L.; Kantane, I. The chemical composition of new oat varieties and breeding lines created in Latvia. Acta Biol. Univ. Daugavp. 2015, 15, 367-373.

61. Barczak, B.; Nowak, K. Effect of the sulphur dose and form on yielding and protein content in Komes cultivar of oat grain. Fragm. Agron. 2010, 27, 14-20.

62. Wierzbowska, J. Calcium and magnesium management in plant of spring wheat in conditions of growth regulators and increasing potassium doses use. J. Elem. 2006, 11, 109-118.

63. Pisulewska, E.; Lepiarczyk, A.; Gambuś, F.; Witowicz, R. Yield and mineral composition of brown and yellow-husked oat forms. Fragm. Agron. 2009, 26, 84-92.

64. Gondek, K.; Filipek-Mazur, B. Zawartość i pobranie mikroelementów przez owies w warunkach nawożenia kompostami różnego pochodzenia w aspekcie wartości paszowej i wpływu na środowisko. Woda-Środowisko-Obsz. Wiej. 2005, 5, 81-93.

65. Zaguła, G.; Zardzewiały, M.; Saletnik, B.; Bajcar, M.; Czernicka, M.; Grabek-Lejko, D.; Kasprzyk, I.; Puchalski, C. Effects of fertilizer use and pre-sowing seed stimulation with a magnetic field on the mineral content and yield of three varieties of sugar beet roots. J. Elem. 2017, 4, 1401-1414. [CrossRef]

66. Rochalska, M.; Orzeszko-Rywka, A. Magnetic field treatment improves seed performance. SST 2005, 33, 669-674. [CrossRef]

67. Gusta, L.V.; Kirkland, K.J.; Austenson, H.M. Effects of a brief magnetic exposure on cereal germination and seedling growth. Can. J. Plant Sci. 1978, 58, 79-86. [CrossRef]

68. Bujak, K.; Frant, M. Influence of pre-sowing grain stimulation with variable magnetic field on technological quality of spring wheat grown on a soil developed from loess. Acta Agrophys. 2009, 14, 19-29.

69. Esitken, A.; Turan, M. Alternating magnetic field effects on yield and plant nutrient element composition of strawberry (Fragaria x ananassa cv. Camarosa). Acta Agric. Scand. Sect. B Soil Plant Sci. 2004, 54, 135-139. [CrossRef]

70. Marmouzi, I.; Saidi, N.; Meddah, B.; Mouksaim, M.; Gharby, S.; El Karbane, M.; Serragui, S.; Cherrah, Y.; Faouzi, M.E.A. Nutritional characteristics, biochemical composition and antioxidant activities of Moroccan oat varieties. J. Food Meas. Charact. 2016, 10, 156-165. [CrossRef]

71. Emmonds, L.C.; Peterson, D.M. Antioxidant activity and phenolic content of oat as affected by cultivar and location. Crop Sci. 2011, 41, 1676-1681. [CrossRef]

(C) 2020 by the authors. Licensee MDPI, Basel, Switzerland. This article is an open access article distributed under the terms and conditions of the Creative Commons Attribution (CC BY) license (http://creativecommons.org/licenses/by/4.0/). 